\title{
Use of black soldier fly and house fly in feed to promote sustainable poultry production
}

\author{
A. Dörper ${ }^{1 *}$, T. Veldkamp ${ }^{2}$ and M. Dicke ${ }^{1}$ \\ ${ }^{1}$ Laboratory of Entomology, Wageningen University E Research, P.O. Box 16, 6700 AA Wageningen, the Netherlands; \\ ${ }^{2}$ Wageningen Livestock Research, De Elst 1, 6700 AH Wageningen, the Netherlands; anna.doerper@wur.nl
}

Received: 1 July 2020 / Accepted: 27 August 2020

(c) 2020 Wageningen Academic Publishers

OPEN ACCESS CC) (ㄱ) (2)

REVIEW ARTICLE

\begin{abstract}
The growing human population, changing dietary habits and intensifying competition between food and feed production underline the urgent need to explore novel sustainable production chains. In the past, the poultry sector has gained popularity due to its superior environmental and economic benefits compared to other livestock production systems. Therefore, it is of special interest to focus on refinement and innovation along the value chain to further improve the sector's sustainability. One major issue is the transition towards sustainable protein sources in poultry feed. In this regard, insects are the secret rising stars. Insect species such as the black soldier fly (Hermetia illucens) and house fly (Musca domestica) have been proposed for farming as multifunctional mini-livestock for feed. One major property of these flies is that larvae can convert low-quality organic waste streams into valuable body mass containing high levels of high-quality protein and fat. Furthermore, the larvae are reported to have health-and welfare-promoting effects due to bioactive compounds and poultry having a natural interest in them. The aim of the current paper is to discuss the state-of-the-art of using black soldier fly and house fly larvae as components of poultry feed and to highlight knowledge gaps, future opportunities and challenges. Some first studies have focussed on the successful partial replacement of soybean meal or fishmeal by these insects on poultry performance. However, since the sector is still in its infancy several uncertainties remain to be addressed. More research is required on identifying optimal inclusion levels, clearly differentiating between insect products based on their nutritional value and health-stimulating effects, and comparing the potential of insect products across species.
\end{abstract}

Keywords: black soldier fly, Hermetia illucens, health and welfare, house fly, Musca domestica, nutritional value, poultry feed

\section{Global challenges for the poultry feed industry}

Producing insects as feed has started in recent years and this industry is expected to grow exponentially in the near future, given that insects are expected to soon be authorised as pig and poultry feed in the EU (IPIFF, 2018). The new insect sector provides animal protein through a sustainable production process with low-value inputs, high-value outputs and low environmental impact and can become an important element of the circular economy (Dicke, 2018). For a novel, circular and sustainable way of producing feed, insects provide an excellent opportunity because various species can be reared on organic left-over streams. Fly larvae are important insects used as feed because they have excellent nutritional quality and can be grown sustainably on various organic waste streams (Bava et al., 2019; Jucker et al., 2019; Miranda et al., 2020; Ocio et al., 1979). Therefore, this review focuses on the application of two fly species that are currently produced as a natural ingredient in poultry feed: black soldier fly (BSF; Hermetia illucens) and house fly (HF; Musca domestica). Recent literature on BSF- and HF-based poultry feed is evaluated for effects on nutrient digestibility, growth performance, product quality, and health and welfare.

Within the last decade the global human population has grown to about 7.8 billion people (FAOSTAT, 2019) and is forecasted to increase to 9.7 billion in 2050 (FAO, 2018). This will increase the need for food and feed, while rising 
incomes in especially East and Southeast Asia will shift consumer patterns towards enhanced meat consumption (OECD/FAO, 2019). Therefore, one of the major challenges the food and feed sectors face is the increasing demand for protein (OECD/FAO, 2019; Van Krimpen and Hendriks, 2019). Competition between food and feed production is expected to increase even more, because considerable protein quantities in animal feed originate from sources also edible for humans (Mottet et al., 2017).

The protein component of feed may originate from different sources: crops (cereals, oilseeds and pulses) and non-plant sources (e.g. former foodstuff, fishmeal and processed animal protein) (EC, 2019). Currently, most commonly used protein sources in commercial livestock and fish feed formulations are soybean meal and fishmeal (FAO, 2008; Olsen and Hasan, 2012). The biggest downside of using plant-based protein sources in animal feed, such as soybean meal, is that their cultivation requires a lot of land and water (FAO, 2009). Soybean production leads to deforestation, especially in the Amazon (Hecht, 2005) and, additionally, soybean meal requires long-distance transportation. Because global arable land is limited, increasing food and feed demands will intensify the trade-off between crop land used for food versus feed (OECD/FAO, 2019).

Fishmeal represents a highly valuable protein source in animal feed that is mainly incorporated in aquafeed, but also in feed for other livestock such as poultry and pigs (FAO, 2008; OECD/FAO, 2019). In comparison to soybean meal, fishmeal reaches about four-fold higher market prices. It is expected that fishmeal will gradually be replaced by cheaper oilseed products (OECD/FAO, 2019). Moreover, due to overexploitation of the ocean, fishmeal bears the risk of becoming even rarer in the future (Van Huis et al., 2013).

The production of protein sources for feed is unevenly distributed (Van Krimpen and Hendriks, 2019). Most countries are highly dependent on international trade. The EU, for instance, imports about one quarter of its feed protein. When focussing on the EU's self-sufficiency rate of soybean meal this value even drops to $3 \%(E C, 2019)$. The combined effect of land limitation and market dominance of export countries is predicted to amplify competition and to increase market prices (Clément et al., 2018; OECD/ FAO, 2019).

In conclusion, feed protein sources are important, but limited resources which will become even more valuable in the next decades. The current protein sources for feed, fishmeal and soybean meal, are not sustainable. Consequently, both products are not suitable to meet with the rapidly growing demand. The development of new, sustainable, protein-rich resources is therefore of major importance.

\section{Poultry production: a rising sector}

Animal products commonly incorporated in human diets are pork, beef, chicken, milk, and eggs. Of these, the poultry sector recently emerged as one of the most important agricultural branches experiencing rising global attention (Augère-Granier, 2019; OECD/FAO, 2019). Several facts favour the production and consumption of these products. One reason is the increasing public attention towards higher sustainability standards in livestock husbandry (OECD/FAO, 2019). The environmental impact of poultry products is comparatively low (De Vries and De Boer, 2010; Flachowsky et al., 2018). In contrast to other livestock products, chicken meat and eggs have the lowest water and carbon footprint per $\mathrm{kg}$ edible protein. Also, land use efficiency per $\mathrm{kg}$ edible protein is very high and only exceeded by dairy milk production (Flachowsky et al., 2018). An effective poultry production system should pay full attention to animal health and welfare.

The attractiveness of the two sub-sectors reflects their economic growth in 2008-2018. During this period, chicken meat and egg industries recorded by far the biggest global production increase of $\sim 41$ and $\sim 24 \%$, respectively (FAOSTAT, 2020a). This increase is expected to continue in the future (OECD/FAO, 2019). Eggs are highly nutritious and provide essential and valuable nutrients in addition to protein (Farrell, 2013). As global population growth is expected to be accompanied by economic growth, rising incomes are expected to promote dietary shifts towards higher levels of animal protein inclusion (OECD/FAO, 2019).

This is also true for the poultry meat industry. On a global scale, poultry meat greatly impacts the daily protein supply per capita, and exceeds the protein contribution of pig and cattle meat (FAOSTAT, 2020b). The attractiveness of the sector is equally shared amongst consumers and producers (OECD/FAO, 2019). Compared to other production systems such as cattle and pig husbandry, poultry offers several advantages. First of all, it supplies lean meat, which is increasingly meaningful to consumers due to their rising awareness of healthy foods. Secondly, chickens grown for meat have low feed conversion ratios and short life cycles, which promote flexible production, limited production costs and consequently relatively low product prices (FAO, 2018; OECD/FAO, 2019). Finally, unlike most other meat sources, poultry meat consumption has no religious barriers and therefore has a unique market position (EC, 2018). However, the one-sided selection for low feed conversion and fast growth in broilers has led to severe animal welfare and health problems, such as leg and metabolic disorders (EC, 2016; Wallenbeck et al., 2016).

In conclusion, the poultry sector is important for the production of protein-rich nutritious food, largely 
contributing to the global supply of animal protein. Its main branches are the production of chicken meat and eggs, both showing a steep upward trend in production. The poultry industry is predicted to fulfil a key position in satisfying future rising demands for animal protein. It is, therefore, an essential element to focus on refinement and innovation at every part of the value chain to improve the sector's sustainability.

\section{Poultry production systems}

\section{Broiler production}

Within the poultry sector, chickens raised for meat production are known under the term 'broilers' (EC, 2016). Broiler husbandry can be categorised into rearing systems with an intensive and less intensive production focus. Within the latter category, production is realised with slow-growing broiler strains, while fast-growing broilers dominate in intensive systems (Van Horne, 2018; Vissers et al., 2019). The main difference between the two breeding strategies is the longer growth period of slowgrowing broilers required to reach a marketable weight of $2-2.5 \mathrm{~kg}$. In practice, the growth period varies greatly and ranges between 35 to $81 \mathrm{~d}$, while fast-growing strains are slaughtered at an age of 35-42 d (EC, 2016).

The quantity of alternative production systems keeping slow growing broilers has slightly increased within the past years (Van Horne, 2018). The increase of alternative systems is primarily reasoned by welfare issues emerging in conventional systems. Commonly reported issues are leg weaknesses, reduced active behaviour, disease susceptibility, prevalence of contact dermatitis, and ascites, which can result in mortality (EC, 2016; Wallenbeck et al., 2016). However, fast-growing broiler systems represent the majority. Within the EU, for instance, fast-growing broiler systems cover $90-95 \%$ of broiler production (AugèreGranier, 2019; Van Horne, 2018).

Across EU countries, market share of both systems varies greatly. For instance, within The Netherlands 30\% of marketed broiler meat is based on slow-growing strains (Saatkamp et al., 2019; Stadig, 2019). Alternative husbandry systems using slow-growing broilers emerged rapidly in the Netherlands from 2013 onwards. As for now, this development is unique worldwide (Saatkamp et al., 2019).

Slow-growing broilers experience better welfare (Vissers et al., 2019), due to lower daily weight gain and altered morphological conformation, improved walking abilities (Corr et al., 2003; Wallenbeck et al., 2016), and higher active behaviour (Wallenbeck et al., 2016; Wilhelmsson et al., 2019). Moreover, slow-growing broilers exhibit lower mortality rates (Dixon, 2020) and similar (Sakkas et al., 2018) or improved immune responses (Giles et al., 2019).
Sustainability in animal husbandry has many elements, including animal welfare, economics, environmental impact and social justice (Fernyhough et al., 2020). Within this context one may realise that farm systems that produce slow-growing strains also negatively impact some aspects of sustainability. The improved animal welfare compared to fast-growing strains is accompanied by a higher economic and ecological burden due to higher feed conversion ratios (Rezaei et al., 2018), longer life cycles, higher feed and energy requirements (Tallentire et al., 2018), lower breast meat yield, and meat quality (Fanatico et al., 2008; Quentin et al., 2003). The market price of meat of slow-growing strains is higher and by this the economic burden is reduced. Society in general has a more critical attitude to animal meat production because of ethics (Lund et al., 2016). Thus, the poultry meat sector faces the dilemma of a trade-off between different elements of sustainability.

\section{Laying hen production}

The European egg sector is also of great importance because it is the second producer worldwide, behind China (AugèreGranier, 2019). Based on the annual production in 2018, about 7.1 million tonnes of hen eggs were produced, of which $9.9 \%$ were produced in The Netherlands (FAOSTAT, 2020a).

Laying hens are reared within four major husbandry systems: enriched cages, barn-, free range- and organic systems (Augère-Granier, 2019). Laying hens used within these production systems can be divided into two categories which reflect strains producing eggs with either white or brown eggshell colour (Leenstra et al., 2012). In practice, the eggshell colour is commonly pre-indicated by the colour of the feather dress (white or brown, Leenstra et al., 2012) or earlobe (white or red, Nie et al., 2016). Several regions show a specific preference for one of the two eggshell colours. For example, within the EU brown eggs dominate the market reflecting consumer preference (International Egg Commission, 2019).

The genetic trait for brown eggshell colour in laying hens negatively impacts economic and environmental aspects. White strains for instance are known to have a lighter body weight (Bean and Leeson, 2003; De Haas et al., 2013; Singh et al., 2009), slightly lighter eggs, equal egg productivity (Bean and Leeson, 2003; Onbaşllar et al., 2015; Singh et al., 2009), and more favourable feed conversion ratios (De Haas et al., 2013; Fernyhough et al., 2020; Onbaşılar et al., $2015)$ in comparison to their brown companions. Hence, from an economic and environmental point of view white egg-producing strains have a distinct advantage over brown egg-producing strains. The production of brown eggs seems, therefore, mainly driven by consumer perception and preference. 
In some EU countries there is a noticeable change within the market share from brown towards white layers (International Egg Commission, 2015). While the ratio in The Netherlands in 2011 was 55:45, the ratio shifted in 2019 to 35:65, respectively. Also China, the global leader in egg production, produced in 2011, 82\% of their eggs with brown eggshell colour, while this proportion reduced substantially to 65\% in 2019 (International Egg Commission, 2011, 2019). One reason for this development is the reduced aggressive behaviour of white layers (International Egg Commission, 2015). Hence, these strains are of special interest in countries where beak trimming is prohibited (Fernyhough et al., 2020; International Egg Commission, 2015).

The literature comparing feather pecking and plumage scores between white and brown layers appears rather inconclusive. Some reports are in accordance with the previous statement and suggest less issues regarding feather loss in white layers (Damme and Urselmans, 2013; Odén et al., 2002; Struthers et al., 2019). Other authors even indicate worse feather conditions in white layer flocks (De Haas et al., 2013; Dixon and Duncan, 2010; Leenstra et al., 2012; Uitdehaag et al., 2008). Variation in the literature can possibly be attributed to the multifactorial nature of feather pecking (Nicol et al., 2013).

Equivalent to the debate about slow- vs fast-growing broiler strains, also eggshell colour in strains of laying hens differently affects components of sustainability. While economic and environmental characteristics favour strains laying white eggs, consumer beliefs drive production systems towards brown strains.

In summary, sustainability of the poultry sector has several dimensions (animal welfare, economics, environmental impact and social justice), that in many instances trade off. The main component appears to be a potential trade-off between animal welfare and resource friendly production. The main challenge will be to find a balanced solution or to explore new approaches combining those elements, such as environmental enrichment for resource-efficient poultry strains. Reducing pressure on the feed market by presenting an alternative and more environmentally sustainable protein source such as insects as (part of) animal feed might be an option to positively impact poultry health and welfare while production efficiency is guaranteed.

\section{Insects as part of the solution}

To improve sustainable production, the use of insects in animal feed has gained great interest over the past years, which is highlighted by the strong increase in academic publications on this topic (Van Huis, 2020). The increasing attention for the use of insects in animal feed is justified by their qualitatively high nutritional content, but also by their potential to act as health promoters for livestock.

\section{Nutritional value}

Currently, insect species including BSF, HF, yellow mealworm (TM), lesser mealworm, house cricket, banded cricket, and field cricket have been approved to be used in animal feeds for specific purposes (EC, 2017). Among these insects, the first three species have been proposed to be most promising for production as feed components (Sogari et al., 2019; Van Huis, 2020; Veldkamp et al., 2012). Although these insects have a high protein and fat content the proximate analysis demonstrates the prevalence of nutritional differences (Table 1). HF larvae for instance contain higher levels of crude protein and lower levels of crude fat than BSF (Makkar et al., 2014). However, the composition can be highly variable dependent on the larval rearing substrate (Schmitt et al., 2019).

When focusing on amino acid (AA) profiles, comparable values have been reported for insect sources and soybean meal (Makkar et al., 2014; Veldkamp and Van Niekerk, 2019). Insects are particularly rich in lysine and methionine (Makkar et al., 2014), while cystine appears to be the most limiting AA (Makkar et al., 2014; Veldkamp et al., 2012). Regarding animal feed production, it is essential that insects fulfil the requirements of the target animal. In poultry diets, most limiting AAs are methionine, lysine, tryptophan, and threonine (Fernandez et al., 1994; Harms and Ivey, 1993). According to the essential AA index for broilers, BSF, HF, and TM larvae exceed the required quantities of essential AA (Veldkamp and Bosch, 2015). Thus, insects have a great

Table 1. Proximate composition (minimum and maximum) of yellow mealworm, black soldier fly, and house fly larvae.

$\begin{array}{lllll} & \begin{array}{l}\text { Dry matter (DM) } \\ \text { g/kg fresh }\end{array} & \begin{array}{l}\text { Crude protein } \\ \text { g/kg DM }\end{array} & \begin{array}{l}\text { Crude fat } \\ \text { g/kg DM }\end{array} & \text { References } \\ \text { Yellow mealworm } & 364-424 & 494-661 & 245-360 & \begin{array}{c}\text { Azagoh et al., 2016; Elahi et al., 2020; Ghaly and Alkoaik, 2009; } \\ \text { Ochoa Sanabria et al., 2019 }\end{array} \\ \text { Black soldier fly } & 300-388 & 371-492 & 72-387 & \begin{array}{r}\text { Finke, 2013; Jucker et al., 2020; Schmitt et al., 2019; Star et al., } \\ \text { 2020; Veldkamp and van Niekerk, 2019; Woods et al., 2020 }\end{array} \\ \text { House fly } & 205-276 & 579-646 & 156-245 & \text { Fitches et al., 2019; Qi et al., 2019; Wang et al., 2013 }\end{array}$


potential to substitute soybean meal in poultry diets based on the AA profile.

\section{Potential health promotors}

In addition to their excellent nutritional composition, insects recently gained further attention due to health promoting characteristics of specific components such as chitin, antimicrobial peptides and lauric acid (Figure 1).

\section{Chitin}

Chitin is, after cellulose, the most abundant polysaccharide in nature. Its molecular structure is nearly identical to cellulose; chitin possesses acetamide groups attached at the C-2 position, thus chitin is cellulose's 2 -acetamido derivative (Rinaudo, 2006). Chitin is a main component of the exoskeleton of insects (Rinaudo, 2006), which fulfils structural functions and protects the organism against environmental hazards (Lee et al., 2008). It is naturally embedded within a matrix with proteins, lipids and minerals (Józefiak et al., 2016). Enzymes such as chitinase break down the molecule into chitin derivatives like chitosan (Shahidi and Abuzaytoun, 2005). Due to the polyanionic nature of chitosan, the molecule can turn into a strong chelator and bind metal ions (Rinaudo, 2006). Since most animals are unable to produce chitinase in the gastrointestinal tract (Shahidi and Abuzaytoun, 2005), chitin is considered as an indigestible fibre (Tabata et al., 2017). However, mRNA expression of the gene encoding for chitinase within the glandular stomach of chickens, indicates that chickens are able to digest chitin to a certain extent (Suzuki et al., 2002; Tabata et al., 2017).

Chitin and its derivatives have been found to positively impact the health status of animals. For instance, chitosan oligosaccharides (COS) supplemented to broiler diets significantly increased the relative weight of important immunological organs such as the spleen, bursa of Fabricius and thymus (Chi et al., 2017). Similar experiments with COS in broiler diets highlighted its potential to enhance IgM levels and proinflammatory cytokine expression in blood serum (Deng et al., 2008). Moreover, chitin derivatives can also serve as a substrate for caecal bacteria in chickens. The alteration of the caecal microbial community influences the health status of chickens, because microorganisms play a key role in shaping the immune system (Li et al., 2007). Based on these findings, provision of chickens with insects containing chitin is expected to impact health parameters. Moreover, because the structure of chitin varies between insect species (Kaya et al., 2015) and the effect of chitin on the immune system is complex and size-dependent (Lee $e t$ al., 2008), their health promoting properties might differ.

To evaluate the impact of insect chitin as feed component on the immune system of animals, the analysis of ingested chitin levels is indispensable. Currently, several methods are available for quantification of chitin in whole insects (Finke, 2007, 2013; Hahn et al., 2018; Woods et al., 2020). However, due to the application of different methodological

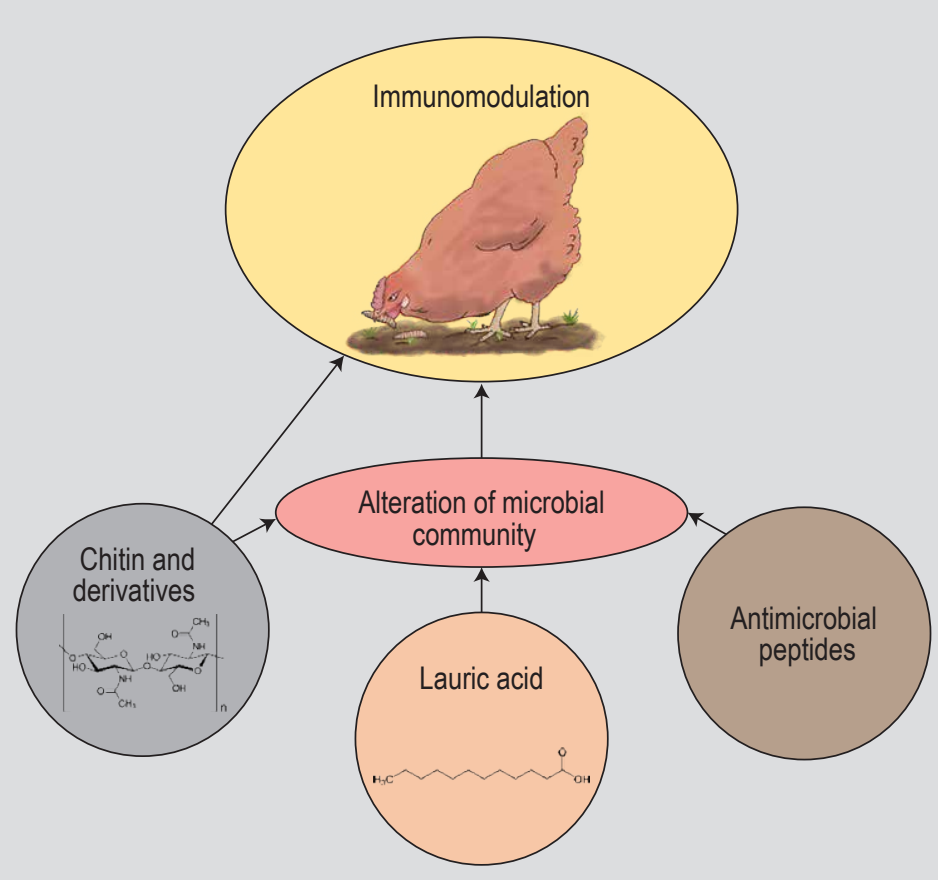

Figure 1. Potential direct and indirect modulation of the poultry immune system by insect chitin, lauric acid, and antimicrobial peptides. 
approaches, results are rather variable (Hahn et al., 2018). For example, reported chitin contents in BSF larvae range from $54 \mathrm{~g} / \mathrm{kg}$ dry matter (DM) (Finke, 2013) to $106 \mathrm{~g} / \mathrm{kg}$ DM (Hahn et al., 2018). Consequently, there is a need for an accurate, practically applicable and uniformly accepted method to determine chitin levels in insects. Moreover, within the cited studies neither the instar nor the age in days of the harvested larvae was mentioned. Chitin levels increase with development of the larvae (Wong et al., 2019). It is of utmost importance to facilitate the comparability of chitin levels among literature.

\section{Lauric acid}

Lauric acid (C12:0) belongs to the group of medium-chain fatty acids (MCFA), which are known to have antibacterial properties (Skrivanova et al., 2006). Insects such as BSF and HF larvae contain considerable amounts of crude fat (Veldkamp et al., 2012). Especially the fat fraction of BSF larvae has been highlighted to contain great quantities of MCFAs and particularly lauric acid (Cullere et al., 2019a; Gasco et al., 2018). The mechanism underlying MCFA disturbance of bacterial development is not fully known to date. Yet, in vitro experiments indicate that MCFAs are able to enter bacterial cells through their membrane (Kim and Rhee, 2013; Skrivanova et al., 2006). The entry process is assumed to lead to membrane damage, which consequently changes the cell's permeability. This damage may further promote the entry of other antibacterial compounds into the cell (Kim and Rhee, 2013).

In vitro analysis of the effects of lauric acid on Clostridium perfringens indeed shows that the MCFAs enter and disrupt the cytoplasmatic structure of the cell, although the bacterial membrane integrity remained intact (Skrivanova et al., 2006). Additional testing with different concentrations of MCFA on C. perfringens development identified 0.5 $\mathrm{mmol} / \mathrm{l}$ lauric acid as the minimum inhibitor concentration required to induce antibacterial activity. However, when Escherichia coli bacteria were treated with 0.125 to 1.5 $\mathrm{mmol} / \mathrm{l}$ lauric acid, only negligible bactericidal effects were recorded (Kim and Rhee, 2013). Possibly membrane differences between Gram-negative and -positive bacteria may play a role in this. Gram-positive bacteria are more susceptible to damage caused by MCFAs, whereas it seems rather challenging to successfully inactivate Gram-negative bacteria with MCFAs (Kim and Rhee, 2013; Skrivanova et al., 2006). Also, the type of MCFAs appears to play an important role. The application of the MCFA caprylic acid, for instance, had dose-dependent lethal effects on Gramnegative E. coli bacteria (Kim and Rhee, 2013; Skrivanova et al., 2006). Furthermore, lower $\mathrm{pH}$ values resulting from MCFAs promoted bacterial cell death (Kim and Rhee, 2013).

Because especially Gram-positive bacteria seem to be sensitive to MCFAs, this property could be used to reduce pathogen loads in livestock. For example, in broiler chickens challenged with $C$. perfringens, supplementation of experimental diets with MCFA (C6-C12), significantly reduced the prevalence of necrotic enteritis lesions in the small intestine. The authors suggest that this was due to growth inhibition and lethal effects of MCFAs on the bacterium (Timbermont et al., 2010). Thus, the provision of insects in chicken feed may modify the microbial community and reduce the prevalence of pathogens in the gastrointestinal tract.

\section{Antimicrobial peptides}

An important category of molecules with immunomodulatory functions contained in insects are antimicrobial peptides (AMPs; Bulet et al., 1999), also known as host defence peptides (Cole and Nizet, 2016). AMPs are part of the innate immune system of various living organisms besides insects, including plants, fungi, bacteria, and animals (Józefiak and Engberg, 2017). Their specific mode of action varies on the basis of their amino acid sequence and structural organisation (Bulet et al., 1999).

AMPs currently gain immense global attention, due to their antibacterial function (Gasco et al., 2018) and successful action against multi-drug resistant pathogens, which are a rising threat for society (Bahar and Ren, 2013). For instance, HF larvae and pupae express AMP's such as defensin in several tissues, which act upon invading Gram-positive bacteria (Andoh et al., 2018; Dang et al., 2010). Experiments with HF AMPs even showed that the administration to Salmonella pullorum infected chickens can serve as effective treatment of the intestinal disease, without having negative effects on mucosal epithelial cells (Wang et al., 2017). The novel defensin-like peptide 4 (DLP4) detected in BSF larvae exhibits activity against Gram-positive bacteria including methicillin-resistant Staphylococcus aureus (Park et al., 2015). While insects contain a wide spectrum of AMPs which have been identified to function against Grampositive bacteria, most of them show no or little activity against Gram-negative bacteria (Dang et al., 2010; Meylaers et al., 2004; Park et al., 2015; Vogel et al., 2018).

To benefit from insect AMPs in animal feed it is important to understand their biosynthesis. For example, although defensin in HF larvae and pupae is continuously expressed at a low level, injury of HF larvae and pupae by a needle or immunised with a needle dipped in a bacterial suspension sharply elevates defensin levels (Andoh et al., 2018; Dang et al., 2010). Due to larval and pupal immunisation, defensin can reach values up to 300 and 600 times higher than before immunisation (Andoh et al., 2018). A similar infectiondependent synthesis of DLP4 is observed in BSF larvae, though DLP4 expression is absent in unchallenged larvae (Park et al., 2015). Besides, AMP expression has been found to be diet-dependent (Vogel et al., 2018). AMP levels in 
insect products might be further influenced by larval processing. Although some AMPs have been found to be thermal stable (Hao et al., 2008; Li et al., 2017), heat treatment might largely impact heat labile AMPs and reduce their presence in the final product. Currently, various insect products in addition to live larvae are applied in animal feed. This includes the use of non-defatted or defatted insect meal. To the best of our knowledge, there is no information available on AMP activity in those manufactured insect products. Such information would be highly valuable.

In conclusion, current knowledge indicates that AMP production in insects is variable and is affected by injury-, infection- or diet-dependent induction. Rearing conditions and processing of insect larvae therefore likely influence their impact on immunomodulatory functions when used in livestock feed. It is, therefore, important to determine AMP levels in insect products to properly estimate their effect on chickens.

\section{BSF and HF in poultry feed}

Although there are yet only few studies available examining the use of BSF and HF larvae in animal feed, some studies already reported their successful inclusion in poultry diets. To prevent that conclusions are affected by nutritional imbalances between experimental diets, the following paragraphs focus only on literature explicitly indicating the comparison of isonitrogenous and isocaloric diet formulations. Table 2, 3 and 4 report the effect of dietary BSF and HF products inclusion in broiler, laying hen and other poultry feed and their effect on digestibility, performance, product quality, and animal health.

\section{Broilers}

\section{Production performance}

Few publications are available regarding the application of BSF or HF larvae in broiler nutrition. Incorporation of up to $10 \%$ of defatted BSF larval meal in broiler diets revealed an increased feed intake (FI) and average daily gain (ADG) during the first phase of rearing. On the other hand, the development of broilers receiving higher levels of partially defatted BSF larvae were rather hampered (Dabbou et al., 2018) and further led to the reduction of bacterial diversity in the caeca and intestinal mucin production (Biasato et al., 2020). Also inclusion of 6 and 8\% BSF larval meal improved the animal performance by reducing the FI and FCR while the final BW was unaffected (Attivi et al., 2020).The findings give an indication that in order to maintain favourable performance results, insect inclusion in broiler diets should be restricted to an optimal inclusion level which needs to be defined by further research (Dabbou et al., 2018). Inclusion of HF larval meal lower than $2 \%$ increased the final BW, and BWG at 1.6, and 2\% of inclusion. Also FI was influence which led to higher uptake of feed at 0.8 and $1.2 \%$ HF larval meal inclusion. The FCR also indicated a positive development by showing lower values at all inclusion levels (Okah and Onwujiariri, 2012). In contrast, inclusion of up to $22 \% \mathrm{HF}$ larval meal did not alter nutrient retention (Adeniji, 2007) and performance parameters of broilers (Adeniji, 2007; Ocio et al., 1979). Furthermore, results for the apparent ileal digestibility and true ileal digestibility of AA of HF larval meal and fishmeal investigated in broilers identify AA digestibility in HF larval meal comparable with AA digestibility in fishmeal (Hall et al., 2018). Because

Table 2. Inclusion of black soldier fly (BSF) and house fly (HF) products in broiler diets and their effect on digestibility, performance, product quality, and animal health, as reported in studies that compare diets that are isonitrogenous and isocaloric.

\begin{tabular}{|c|c|c|c|c|c|}
\hline Age & Insect product & $\begin{array}{l}\text { Target } \\
\text { replacement }\end{array}$ & $\begin{array}{l}\text { Insect } \\
\text { inclusion \% }\end{array}$ & $\begin{array}{l}\text { Results (digestibility, performance, product quality and animal } \\
\text { health) })^{1}\end{array}$ & Reference $^{2}$ \\
\hline $1-35 d$ & $\begin{array}{l}\text { partially defatted } \\
\text { BSF larval meal }\end{array}$ & $\begin{array}{l}\text { soybean meal, } \\
\text { soybean oil, corn } \\
\text { gluten meal }\end{array}$ & $0,5,10,15$ & $\begin{array}{l}\text { Improved LW and DFI during starter period, improved final LW, no effect } \\
\text { on FCR at }<10 \% \text { BSF inclusion. Lower LW during growing and finisher } \\
\text { period and increased FCR at } 15 \% \text { BSF meal inclusion. }\end{array}$ & $\begin{array}{r}\text { Dabbou et } \\
\text { al., } 2018\end{array}$ \\
\hline $1-35 d$ & $\begin{array}{l}\text { partially defatted } \\
\text { BSF larval meal }\end{array}$ & $\begin{array}{l}\text { soybean meal, } \\
\text { soybean oil, corn } \\
\text { gluten meal }\end{array}$ & $0,5,10,15$ & $\begin{array}{l}\text { Mucin staining intensity in the intestinal villi reduced at } 10 \text { and } 15 \% \text { meal } \\
\text { inclusion. Shift in caecal microbiota. }\end{array}$ & $\begin{array}{l}\text { Biasato et al., } \\
2020\end{array}$ \\
\hline 14- $56 d$ & BSF larval meal & fishmeal & $0,2,4,6,8$ & $\begin{array}{l}\text { Lower feed intake and FCR at } 6 \text { and } 8 \% \text { inclusion. Lower BWG at } 2,4 \text { and } \\
6 \% \text { inclusion. Higher BWG at } 8 \% \text { inclusion. No difference in final BW. } \\
\text { Lower Gizzard weight and intestinal length at } 4,6 \text {, and } 8 \% \text { inclusion. } \\
\text { No difference in total protein, lower albumin at 2, 4, and } 6 \% \text { inclusion and } \\
\text { higher values at } 8 \% \text { inclusion. } \\
\text { Lower level of uric acid at any inclusion level and higher triglyceride values } \\
\text { for } 4,6 \text {, and } 8 \% \text { inclusion. } \\
\text { Lower apparent crude protein digestibility at } 2,4 \text {, and } 6 \% \text { inclusion level. }\end{array}$ & $\begin{array}{l}\text { Attivi et al., } \\
2020\end{array}$ \\
\hline
\end{tabular}


Table 2. Continued

\begin{tabular}{|c|c|c|c|c|c|}
\hline Age & Insect product & $\begin{array}{l}\text { Target } \\
\text { replacement }\end{array}$ & $\begin{array}{l}\text { Insect } \\
\text { inclusion \% }\end{array}$ & $\begin{array}{l}\text { Results (digestibility, performance, product quality and animal } \\
\text { health) }\end{array}$ & Reference $^{2}$ \\
\hline $1-35 d$ & $\begin{array}{l}\text { defatted BSF larval } \\
\text { meal }\end{array}$ & $\begin{array}{l}\text { soybean meal, } \\
\text { soybean oil, corn } \\
\text { gluten meal }\end{array}$ & $0,5,10,15$ & $\begin{array}{l}\text { Increased carcass weight and breast yield at }<10 \% \text { BSF meal inclusion. } \\
\text { Linear increase of meat redness to a maximum at } 15 \% \text { BSF inclusion. } \\
\text { Linear decrease of meat yellowness, CP, MUFA, and reduced moisture } \\
\text { and PUFA as inclusion level was increased. }\end{array}$ & $\begin{array}{l}\text { Schiavone et } \\
\text { al., } 2019\end{array}$ \\
\hline $1-42 d$ & live BSF & - & $\begin{array}{l}0,5,5,10 \\
10\end{array}$ & $\begin{array}{l}\text { Live BSF were given at inclusion levels of } 5 \text { and } 10 \% \text { of the dietary FI. } \\
\text { Larvae were provided } 2 \text { (BSF52, BSF102) or } 4 \text { (BSF54, BSF104) times } \\
\text { a day. } \\
\text { Final BW lower in BSF102. No influence on ADMI and ADMEI. } \\
\text { No effect on shuffling, perching, stretching and comfort behaviour. All } \\
\text { remaining behaviours (standing idle, walking, eating, drinking, foraging, } \\
\text { ground pecking, resting, and activity) were affected by treatment, week, } \\
\text { and/or interaction. Higher ground pecking and total foraging at any } \\
\text { inclusion level and provision level at any timepoint (week). Despite week } \\
1 \text { group BSF104 had consistently lower values for resting and higher } \\
\text { values general activity than the control group. } \\
\text { Food pad dermatitis was not affected. Hock burn score was higher in } \\
\text { control group than BSF102 and BSF104. Higher gait scores in control } \\
\text { group compared to BSF54, BSF102 and BSF104. }\end{array}$ & $\begin{array}{l}\text { Ipema et al., } \\
2020\end{array}$ \\
\hline $1-35 d$ & HF larval meal & fishmeal & $\begin{array}{c}0,0.8,1.2 \\
1.6,2\end{array}$ & $\begin{array}{l}\text { Increased BW at } 0.8,1.2 \text {, and } 1.6 \% \text { HF meal inclusion. Higher BWG at } \\
1.6 \text { and } 2 \% \text { inclusion. Higher feed intake at } 0.8 \text { and } 1.2 \% \text { inclusion. FCR } \\
\text { lower at any inclusion level. Lower dressing } \% \text { at } 0.8 \% \text { inclusion. Lower } \\
\% \text { of the heart at } 1.2,1.6 \text {, and } 2 \% \text { inclusion. Larger } \% \text { of Gizzard at } 0.8 \text {, } \\
1.6 \text {, and } 2 \% \text { inclusion. Higher } \% \text { inguinal fat at } 1.2 \text { and } 1.6 \% \text { of inclusion. }\end{array}$ & $\begin{array}{l}\text { Okah and } \\
\text { Onwujiariri, } \\
2012\end{array}$ \\
\hline $1-42 d$ & HF larval meal & groundnut cake & $\begin{array}{r}0,5.5,11.0 \\
16.5,22.0\end{array}$ & No effect on nutrient retention and performance parameters. & Adeniji, 2007 \\
\hline $1-28 d$ & HF larval meal & fishmeal & 0,4 & No effect on any performance parameter. & $\begin{array}{l}\text { Ocio et al., } \\
1979\end{array}$ \\
\hline $21-28 d$ & HF larval meal & fishmeal & $\begin{array}{c}0,0,0,20 \\
40,60\end{array}$ & $\begin{array}{l}\text { Regression analysis was used to investigate the digestibility of AA. } \\
\text { Therefore, diets contained either } 20,40 \text {, and } 60 \% \text { fishmeal, or } 20,40 \text {, } \\
\text { and } 60 \% \text { HF larval meal. } \\
\text { AIDC and TIDC of fishmeal and HF larval meal was comparable. }\end{array}$ & $\begin{array}{l}\text { Hall et al., } \\
2018\end{array}$ \\
\hline $1-31 d$ & HF larval meal & soybean meal & $0,4,5,6$ & $\begin{array}{l}\text { Higher DM, EE, and ash digestibility and lower crude fibre digestibility at } \\
6 \% \text { inclusion, higher CP digestibility at } 4 \text { and } 6 \% \text { inclusion. Increased } \\
\text { BW, reduced FI, and FCR, higher dressing \%, and higher apparent } \\
\text { metabolisable energy at any level of meal provision. Unchanged } \\
\text { organoleptic meat properties. }\end{array}$ & $\begin{array}{l}\text { Khan et al., } \\
\text { 2018a }\end{array}$ \\
\hline $1-31 d$ & HF larval meal & soybean meal & $0,1,2,3$ & $\begin{array}{l}\text { Apparent metabolisable energy increased at } 2 \text { and } 3 \% \text { meal inclusion. } \\
\text { Digestibility of nutrients remained unchanged. Reduced FI and FCR } \\
\text { at any inclusion level. Increased weight gain at } 2 \text { and } 3 \% \text { inclusion. } \\
\text { Dressing } \% \text { of meat increased at } 3 \% \text { meal inclusion. Improved } \\
\text { organoleptic properties due to meal provision. Improved meat tenderness } \\
\text { at } 2 \% \text { meal inclusion, higher juiciness at } 1 \% \text { meal inclusion. Reduced } \\
\text { colour at } 3 \% \text { meal inclusion, better meat flavour at } 1 \text { and } 2 \% \text { meal } \\
\text { inclusion. }\end{array}$ & $\begin{array}{l}\text { Khan et al., } \\
2016\end{array}$ \\
\hline $1-35 d$ & HF larval meal & soybean meal & 0,8 & $\begin{array}{l}\text { No effect on FI, mortality, dressing \%, and sensory meat characteristics. } \\
\text { Increase in BW and reduction of FCR with administration of HF meal. }\end{array}$ & $\begin{array}{l}\text { Khan et al., } \\
\text { 2018b }\end{array}$ \\
\hline $1-42 d$ & HF larval meal & soybean meal & $0,4,8$ & $\begin{array}{l}\text { Linear reduction of BW, } A D G \text {, and increase in FCR during starter phase. } \\
\text { No effect on carcass quality. Alteration of blood parameters were in } \\
\text { physiological range. }\end{array}$ & $\begin{array}{l}\text { Elahi et al., } \\
2019\end{array}$ \\
\hline $1-42 d$ & HF larval meal & soybean meal & $\begin{array}{l}0,5(1-7 d), 4 \\
(8-42 d)\end{array}$ & $\begin{array}{l}\text { Increased BW, ADG, ADFI, and reduced FCR. Increased breast and leg } \\
\text { flavour, aroma and desirability. }\end{array}$ & $\begin{array}{l}\text { Radulović et } \\
\text { al., } 2018\end{array}$ \\
\hline
\end{tabular}


Table 3. Inclusion of black soldier fly (BSF) and housefly (HF) products in laying hen diets and their effect on digestibility, performance, product quality, and animal health, as reported in studies that compare diets that are isonitrogenous and isocaloric.

\begin{tabular}{|c|c|c|c|c|c|}
\hline Age & Insect product & $\begin{array}{l}\text { Target } \\
\text { replacement }\end{array}$ & $\begin{array}{l}\text { Insect } \\
\text { inclusion \% }\end{array}$ & $\begin{array}{l}\text { Results (digestibility, performance, product quality and animal } \\
\text { health) }\end{array}$ & Reference \\
\hline $20-40$ wk & $\begin{array}{l}\text { partially defatted } \\
\text { BSF larval meal }\end{array}$ & soybean meal & $0,7.3,14.6$ & $\begin{array}{l}\text { Lower apparent digestibility of DM and OM at } 14.6 \% \text { inclusion and reduced } \\
\text { apparent } \mathrm{CP} \text { digestibility at any inclusion level. } \\
\text { No effect on weight gain, } \mathrm{FI}, \mathrm{FCR} \text {, and egg weight. Higher lay\% with } 7.3 \% \\
\text { inclusion of meal and higher egg mass at all inclusion levels. Higher } \\
\text { entire intestinal length and of the jejunum as \% of LW. Higher serum } \\
\text { magnesium, potassium, chlorine, globulin and lower albumin to globulin } \\
\text { ratios with } 14.6 \% \text { meal inclusion. Lower bilirubin, cholesterol, triglyceride } \\
\text { and blood urea nitrogen levels at any inclusion level. }\end{array}$ & $\begin{array}{l}\text { Bovera et al., } \\
2018\end{array}$ \\
\hline $67-78$ wk & live BSF larvae & soybean meal & 0,10 & $\begin{array}{l}\text { No effect on FI, FCR, BW, laying rate, egg weight, egg mass, mortality, and } \\
\text { egg quality parameters. Reduction of feather damage. Higher counts of } \\
\text { hens on the floor during the morning and lower counts in the afternoon } \\
\text { when larvae were provided. }\end{array}$ & $\begin{array}{l}\text { Star et al., } \\
2020\end{array}$ \\
\hline $24-45$ wk & $\begin{array}{l}\text { defatted BSF larval } \\
\text { meal }\end{array}$ & soybean meal & 0,17 & $\begin{array}{l}\text { Reduced albumen weight, higher proportion of yolk, and lower albumen } \\
\text { proportion in eggs. Redder egg yolk, higher total carotenoid and } \\
\text { Y-tocopherol levels. Lower MUFA and higher PUFA n-6 in egg yolk. }\end{array}$ & $\begin{array}{l}\text { Secci et al., } \\
2018\end{array}$ \\
\hline $20-36$ wk & $\begin{array}{l}\text { partially defatted } \\
\text { BSF larval meal }\end{array}$ & soybean meal & $0,7.3,14.6$ & $\begin{array}{l}\text { Higher egg weight, yolk weight. Higher eggshell weight with } 7.3 \% \text { meal } \\
\text { inclusion. Lower eggshell \% and eggshell thickness with } 14.6 \% \text { inclusion. } \\
\text { Alteration of the yolk colour. Lower foaming capacity of egg albumen. } \\
\text { Modified physical and chemical characteristics of angel cake. }\end{array}$ & $\begin{array}{l}\text { Secci et al., } \\
2020\end{array}$ \\
\hline $24-45$ wk & $\begin{array}{l}\text { defatted BSF larval } \\
\text { meal }\end{array}$ & soybean meal & 0,17 & $\begin{array}{l}\text { Reduced final LW, and weight gain, FI, FRC, lay \%, egg weight, and } \\
\text { egg mass. High variation in egg size. Higher serum globulin and lower } \\
\text { albumin to globulin ratio. Lower serum cholesterol and triglycerides. } \\
\text { Higher serum calcium and lower chlorine levels. }\end{array}$ & $\begin{array}{l}\text { Marono et al., } \\
2017\end{array}$ \\
\hline $24-45$ wk & $\begin{array}{l}\text { defatted BSF larval } \\
\text { meal }\end{array}$ & soybean meal & 0,17 & $\begin{array}{l}\text { Increased diversity of the microbial population and altered caecal } \\
\text { microbiota in type and relative abundance of microbes. Increased } \\
\text { concentrations of SCFA in ceca. }\end{array}$ & $\begin{array}{l}\text { Borrelli et al., } \\
2017\end{array}$ \\
\hline $25-45$ wk & $\begin{array}{l}\text { defatted BSF larval } \\
\text { meal }\end{array}$ & soybean meal & 0,17 & $\begin{array}{l}\text { Lower apparent ileal digestibility of DM, OM, and CP. } \\
\text { Lower LW. Heavier full digestive tract as \% of LW, higher specific activity of } \\
\text { duodenum maltase, lower activity of jejunum IAP, higher activity of ileal } \\
\text { maltase and saccharase, and lower activity of IAP and yGT. } \\
\text { Higher villi height in duodenum, lower villi height in jejunum and ileum. } \\
\text { Higher crypt depth and lower villi to crypt ratio in ileum Higher volatile } \\
\text { fatty acid production in caecum. Higher acetate, butyrate and total } \\
\text { volatile fatty acid levels in caecum. }\end{array}$ & $\begin{array}{l}\text { Cutrignelli et } \\
\text { al., } 2018\end{array}$ \\
\hline $18-26$ wk & $\begin{array}{l}\text { fresh BSF, dried } \\
\text { BSF, BSF extract }\end{array}$ & fishmeal & $0,8,8,8$ & $\begin{array}{l}\text { Inclusion of any of the BSF products increased the phagocytotic activity of } \\
\text { peritoneal macrophages towards non-protein A Staphylococcus aureus. }\end{array}$ & $\begin{array}{l}\text { Irawan et al., } \\
2019\end{array}$ \\
\hline $20-40$ wk & $\begin{array}{l}\text { partially defatted } \\
\text { BSF larval meal }\end{array}$ & soybean meal & $0,7.3,14.6$ & $\begin{array}{l}\text { Lower villi height, villi to crypt ratio in duodenum and jejunum at any } \\
\text { inclusion level. Higher crypt dept in jejunum at } 14.6 \% \text { inclusion. No effect } \\
\text { compared to the control group on ileal level. } \\
\text { Lower maltase activity in duodenum at } 14.6 \% \text { inclusion and lower IAP } \\
\text { in jejunum at any inclusion level. Lower yGT activity in ileum at } 7.3 \% \\
\text { inclusion. } \\
\text { Higher concentration of acetate, butyrate and total VTA in caecum at } \\
14.6 \% \text { inclusion. Lower concentration of valerianic in caecum at any } \\
\text { inclusion level. Higher level of Isobutyrate and lower level of valerianic as } \\
\% \text { of total VFA in caecum at any inclusion level. Higher level of butyrate } \\
\text { in caecum at } 14.6 \% \text { inclusion. }\end{array}$ & $\begin{array}{l}\text { Moniello et al., } \\
2019\end{array}$ \\
\hline $50-58$ wk & $\begin{array}{l}\text { undefined larval } \\
\text { meal }\end{array}$ & fishmeal & $\begin{array}{l}0,2.4,4.7 \\
\quad 7.1,9.4\end{array}$ & $\begin{array}{l}\text { No effect on FI, weight gain, FCR and mortality. Lower hen-day production } \\
\text { and eggshell weight at highest level of meal inclusion. Lower shell } \\
\text { thickness at } 4.7 \% \text { meal inclusion and shell weight at } 9.4 \% \text { meal } \\
\text { inclusion. Other egg quality parameters unaffected. }\end{array}$ & $\begin{array}{l}\text { Agunbiade et } \\
\text { al. } 2007\end{array}$ \\
\hline $36-44$ wk & HF larval meal & fishmeal & $\begin{array}{c}0,0.9,1.8 \\
2.7,3.6\end{array}$ & $\begin{array}{l}\text { BW, Fl, egg production, egg weight, feed efficiency, and any tested egg } \\
\text { quality characteristics were unaffected. Egg yolk cholesterol, triglyceride, } \\
\text { and calcium lower with inclusion of HF meal, while the concentrations of } \\
\text { phosphorus was increased. }\end{array}$ & $\begin{array}{l}\text { Akpodiete et } \\
\text { al., } 1998\end{array}$ \\
\hline
\end{tabular}

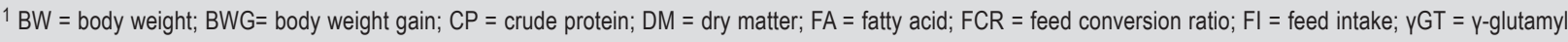
transpeptidase; IAP = intestine alkaline phosphatase; $L W=$ live weight; MUFA = monounsaturated fatty acids; OM = organic matter; PUFA = poly unsaturated fatty acids; SCFA = short chain fatty acids; VFA= volatile fatty acids.
} 
Table 4. Inclusion of black soldier fly (BSF) and housefly (HF) products in other poultry diets and their effect on digestibility, performance, product quality, and animal health, as reported in studies that compare diets that are isonitrogenous and isocaloric.

\begin{tabular}{|c|c|c|c|c|c|c|}
\hline $\begin{array}{l}\text { Poultry } \\
\text { species/type }\end{array}$ & Age & Insect product & $\begin{array}{l}\text { Target } \\
\text { replacement }\end{array}$ & $\begin{array}{l}\text { Insect } \\
\text { inclusion \% }\end{array}$ & $\begin{array}{l}\text { Results (digestibility, performance, product quality } \\
\text { and animal health) }\end{array}$ & Reference \\
\hline Muscovy duck & $3-50 d$ & $\begin{array}{l}\text { partially defatted } \\
\text { BSF larval } \\
\text { meal }\end{array}$ & corn gluten meal & $0,3,6,9$ & $\begin{array}{l}\text { No effect on LW, ADG, FI, and FCR. Haematological } \\
\text { traits were unaffected. Linear reduction of serum } \\
\text { triglycerides, cholesterol, magnesium, alkaline } \\
\text { phosphatase, creatinine, malondialdehyde, and } \\
\text { nitrotyrosine. Linear increase of serum iron. No effects } \\
\text { on histopathological scores. }\end{array}$ & $\begin{array}{l}\text { Gariglio et al., } \\
\text { 2019a }\end{array}$ \\
\hline $\begin{array}{l}\text { Japanese } \\
\text { broiler quail }\end{array}$ & $10-28 d$ & BSF larval meal & $\begin{array}{l}\text { conventional } \\
\text { protein/fat } \\
\text { sources }\end{array}$ & $0,10,10$ & $\begin{array}{l}\text { Increased apparent digestibility of DM, OM and reduced } \\
\text { apparent digestibility of ether extract of quails fed } \\
\text { BSF2. Higher apparent digestibility of starch of quails } \\
\text { fed meal of larvae reared on 100\% layer mash (BSF1). } \\
\text { Higher apparent digestibility of gross energy, higher } \\
\text { metabolisable energy. Reduced slaughter weight and } \\
\text { BWG of quails fed meal of larvae raised on 50:50 fish } \\
\text { offal and layer mash (BSF2). Improved carcass and } \\
\text { breast meat traits of quails fed BSF1. Lower carcass } \\
\text { weight of quails fed BSF2. Lower FI of larval meals } \\
\text { when given a choice. }\end{array}$ & $\begin{array}{l}\text { Woods et al., } \\
2019\end{array}$ \\
\hline Turkey & $1-35 d$ & live BSF larvae & soybean meal & 0,12 & $\begin{array}{l}\text { Lower FCR, higher FI and BWG and reduced aggressive } \\
\text { pecking towards the back and tail-base in the final } \\
\text { week. More feed pecking during first week, less feed } \\
\text { pecking and drinking during the third week and less } \\
\text { object pecking during the fifth week. }\end{array}$ & $\begin{array}{l}\text { Veldkamp and } \\
\text { van Niekerk, } \\
2019\end{array}$ \\
\hline $\begin{array}{l}\text { Japanese } \\
\text { broiler quail }\end{array}$ & $10-28 d$ & BSF larval meal & $\begin{array}{l}\text { conventional } \\
\text { protein/fat } \\
\text { sources }\end{array}$ & $0,10,10$ & $\begin{array}{l}\text { Higher meat cooking losses when fed. Higher protein, } \\
\text { lipid, and cholesterol levels in quail meat of birds } \\
\text { fed BSF1. Alteration of AA content and FA profile of } \\
\text { quail meat fed BSF1. Modified meat juiciness and } \\
\text { fibrousness and colour of quails fed BSF2. }\end{array}$ & $\begin{array}{l}\text { Cullere et al., } \\
2019 \mathrm{~b}\end{array}$ \\
\hline Muscovy duck & $3-50 d$ & $\begin{array}{l}\text { partially defatted } \\
\text { BSF larval } \\
\text { meal }\end{array}$ & corn gluten meal & $0,3,6,9$ & $\begin{array}{l}\text { Apparent digestibility of CP linearly reduced during the } \\
\text { starter phase. Positive linear response of apparent } \\
\text { digestibility of EE during the whole trial. Final LW, ADG, } \\
\mathrm{FI} \text {, and FCR was not affected. Intestinal morphology } \\
\text { remained unaffected. }\end{array}$ & $\begin{array}{l}\text { Gariglio et al., } \\
\text { 2019b }\end{array}$ \\
\hline $\begin{array}{l}\text { Japanese } \\
\text { laying quail }\end{array}$ & $6-13 w k$ & BSF larval meal & fishmeal & $\begin{array}{l}0,3.18,6.37 \\
9.56\end{array}$ & $\begin{array}{l}\text { Egg production was reduced at } 6.37 \text { and } 9.56 \% \text { BSF } \\
\text { meal inclusion. Egg shell thickness was reduced at } \\
9.56 \% \text { of inclusion. Egg Haugh unit, egg weight, egg } \\
\text { yolk index, and egg yolk colour was unaffected. }\end{array}$ & $\begin{array}{l}\text { Suparman et } \\
\text { al., } 2020\end{array}$ \\
\hline $\begin{array}{l}\text { Japanese } \\
\text { broiler quail }\end{array}$ & $10-28 d$ & BSF larval meal & $\begin{array}{l}\text { conventional } \\
\text { protein/fat } \\
\text { sources }\end{array}$ & $0,10,10$ & $\begin{array}{l}\text { Secondary response increased in BSF1. Lysozyme } \\
\text { activity unaffected at day } 27 \text { but at day } 37 \text { activity was } \\
\text { higher in BSF2. Bacterial activity unaffected at both } \\
\text { timepoints. Wing web swelling index significantly higher } \\
\text { in both BSF groups. At day } 27 \text { higher a2-globulin in } \\
\text { both BSF groups and lower y-globulin in BSF2 group. } \\
\text { At day 37, a2 globulin higher in both BSF groups. Other } \\
\text { blood parameters and microbial count in caecal content } \\
\text { remained unaffected. }\end{array}$ & $\begin{array}{l}\text { Pasotto et al., } \\
2020\end{array}$ \\
\hline
\end{tabular}

${ }^{1} \mathrm{AA}=$ amino acid; $\mathrm{ADG}=$ average daily gain; $\mathrm{BW}=$ body weight; $\mathrm{BWG}=$ body weight gain; $\mathrm{CP}=$ crude protein; $\mathrm{DM}=$ dry matter; $\mathrm{EE}=$ ether extract; $\mathrm{FA}=$ fatty acid; $\mathrm{FCR}=$ feed conversion ratio; $\mathrm{FI}$ = feed intake; $\mathrm{OM}=$ organic matter.

diet formulation by Hall et al. (2018) is not in accordance with the above mentioned criterion (iso-nitrogenous and iso-caloric diet formulation), it was chosen to only report results regarding the AA digestibility. Significant positive effects on broiler development, also during later growth stages, have been reported when broilers were provided with up to $8 \%$ of HF larval meal in their diet (Khan et al., 2016, 2018a,b).
Nonetheless, also between studies investigating the same insect species and using comparable inclusion levels, outcome parameters can be highly variable. For instance, broilers fed diets containing in total 4 and $8 \%$ of HF larval meal showed, in contrast to prior findings, reduced ADG during the starter phase, which resulted in higher feed conversion ratios (FCR). Darker colour of HF larval meal is assumed to be responsible for this adverse development 
(Elahi et al., 2019). However, it is also worth noticing that the crude fat (CF) content of HF meal used within these studies varied tremendously, with values of 5.6 (Elahi et al., 2019) and 27.9\% (Khan et al., 2016). Varying levels of CF in insect products may be responsible for differences in performance of broilers (Elwert et al., 2010). This condition furthermore hampers the comparability of results between studies, because the insect products have different nutritional and likely also bioactive values.

\section{Product quality}

Besides affecting broiler performance, inclusion of partly defatted BSF larvae improved carcass traits, such as breast yield (Schiavone et al., 2019). Also the use of HF larval meal beneficially affected broiler dressing percentage (Khan et al., 2018a), while olfactory properties of the meat remained unaffected (Khan et al., 2018a,b) or turned out even more favourable for consumers (Khan et al., 2016; Radulović et al., 2018). In some cases the analysed carcass characteristics were not significantly affected (Elahi et al., 2019). It can be concluded that low levels of inclusion of these insect meals in broiler diets do not negatively influence carcass traits compared to standard feed. A closer analysis of the fatty acid (FA) composition of broiler meat revealed that partly defatted BSF larval meal increased the content of medium unsaturated FA (MUFA) and reduced the occurrence of poly unsaturated FA (PUFA). Since the FA profile of broiler meat is dependent on the feed source (Schiavone et al., 2019) and larval FA composition is dependent on the substrate on which the larvae were reared (Cullere et al., 2019b), the unfavourable development might be adjusted by the choice of larval substrate (Schiavone et al., 2019). Also, the killing method might have an influence on nutritional characteristics of the insect end product (Larouche, 2019).

\section{Health and welfare}

Inclusion of 2, 4, and 6\% of BSF larval meal in broiler diets reduced their blood albumin levels, while $8 \%$ inclusion resulted in higher concentrations. Also triglyceride levels were affected resulting in higher values for 6 and 8\% insect meal inclusion, while uric acid was affected at any inclusion level, indicating efficient utilisation of protein from the diet. However, protein digestibility was adversely influenced at any BSF meal inclusion level lower than 8\% (Attivi et al., 2020). Also the development of intestinal organs was affected by the treatment. Higher inclusion levels reduced the gizzard weight and intestinal length (Attivi et al., 2020). On the other hand, increased gizzard weight was reported when broilers were fed HF larval meal. The reason for this development remains unknown (Okah and Onwujiariri, 2012). Other studies report, in contrast to the expected positive effects of bioactive compounds in insect products on broiler health parameters, that immune organs in broilers were not altered by the inclusion of larval meal of either of the two fly species. Moreover, haematological parameters were within the common physiological range (Dabbou et al., 2018; Elahi et al., 2019). Nonetheless, albumin to globulin ratios were not measured in the studies cited. Because in laying hens these parameters showed significant improvements (Bovera et al., 2018; Marono et al., 2017), it would be an interesting addition to test the effects of BSF and HF products in broiler feed on those parameters as well. Strong positive effects on foraging and general activity behaviour have been found when providing broilers with live BSF larvae. Most pronounced were the effects when the larvae were included to cover $10 \%$ of the DM intake and the provision was spread over 4 feeding moments a day. These behavioural changes likely also reduced the incidence of hock burns and improved gait score (Ipema et al., 2020).

\section{Laying hens}

\section{Production performance}

Including 10\% live BSF larvae, up to 9.4\% undefined larval meal and up to $14.6 \%$ of partially defatted BSF larval meal in layer nutrition showed no change in FI, weight gain and FCR (Agunbiade et al., 2007; Bovera et al., 2018; Star et al., 2020). Moreover, egg weight remained either unaffected (Secci et al., 2018) or increased by administration of BSF meal in layer diets (Secci et al., 2020). However, because higher egg weight was accompanied by lower eggshell thickness, this might impact the fragility of the eggs (Secci et al., 2020). Likewise administration of $9.4 \%$ undefined larval meal reduced the eggshell weight, but also hen egg production (Agunbiade et al., 2007). Furthermore, performance parameters were reduced when higher inclusion levels of defatted BSF larval meal were administered (Marono et al., 2017), which can be explained by either feed colour or chitin levels. Chickens are sensitive to feed colour (Heshmatollah, 2007). Hence, feed colouration may play a role at higher levels of insect meal inclusion, because BSF meal is darker than SBM (Bovera et al., 2018). On the other hand, inclusion of up to $3.6 \%$ HF larval meal did not affect laying hen performance (Akpodiete et al., 1998).

\section{Product quality}

In terms of consumer health, the binding capacity of chitin to nutrients can have favourable effects on end products for humans by reducing serum triglyceride and cholesterol (Bovera et al., 2018; Marono et al., 2017) and therefore egg cholesterol levels (Secci et al., 2018). The same results were found when HF larval meal was administered (Akpodiete et al., 1998). Further egg quality parameters influenced by the inclusion of BSF meal were the alteration of the yolk colour (Secci et al., 2018, 2020), higher proportions of the yolk, lower albumen proportions in the egg, and less egg shell thickness (Secci et al., 2020). The latter might be caused due to the higher egg weight, since calcium resources for 
shell production are limited. In contrast laying hens fed undefined larval meal showed lower egg shell weight at the highest inclusion level (Agunbiade et al., 2007).

\section{Health and welfare}

The production of short-chain fatty acids (SCFA) in the cecum proved to have a positive effect when defatted BSF larval meal was included in the laying hen diet (Borrelli et al., 2017; Cutrignelli et al., 2018). The assumed mechanism is that chitin serves as a fermentation source for caecal microbiota, which leads to the production of SCFA (Borrelli et al., 2017; Cutrignelli et al., 2018). SCFA such as butyric acid serve as an energy source for epithelial cells in the colon and promote mucosal growth. Additionally, SCFA inhibit the growth of acid-intolerant pathogenic bacteria such as C. perfringens, E. coli and Salmonella (Borrelli et al., 2017; Elnesr et al., 2020). However, whether insect products indeed reduce the prevalence of these bacteria requires further investigation.

The better health status of laying hens has been confirmed by serum analysis. Elevated globulin levels and lower albumin to globulin ratios indicate higher resistance and improved immune responses in layers fed partially defatted or defatted BSF meal (Bovera et al., 2018; Marono et al., 2017). However, the inclusion of $7.6 \%$ of partially defatted BSF meal did not alter these immune parameters. Therefore, low levels of insect meal may be insufficient to induce immunological changes at the serum level (Bovera et al., 2018). Besides administration of various BSF products showed that those larval products have the potential to increase the phagocytic activity of macrophages, potentially improving the innate immunity (Irawan et al., 2019). Further promotion of laying hen welfare and health may be achieved by the provision of live larvae instead of larval meal. Insects are part their natural diet and may enable laying hens to express natural behaviour. Feather pecking is a well-known issue in layer flocks. Due to the provision of live larvae as a natural pecking substrate, feather conditions of laying hens were successfully improved. This achievement was likely caused by laying hens spending more time pecking on larvae rather than their pen companions. Besides pecking and ingestion of larvae might be rewarding for laying hens, thus satisfying their need to peck (Star et al., 2020).

In addition to the beneficial prebiotic properties, it was also found that chitin can hinder the digestion of various nutrients (such as protein) by chitin-protein matrixes (Bovera et al., 2018). This is supported by profound reduction of the apparent ileal digestibility of protein, but also organic matter, due to administration of defatted BSF larval meal (Cutrignelli et al., 2018). Also morphological changes such as lower duodenal villi height and lower enzymatic activity are a result of the lower digestibility of the feed (Moniello et al., 2019). Thus, to successfully include insect products in layer diets it seems crucial to determine optimal inclusion levels.

In conclusion, inclusion of BSF and HF larvae in feed improves the performance, product quality, health, and welfare of layer hens dependent on the inclusion level. Furthermore, provision levels for optimal development of hen performance and health do not necessarily coincide. Also storability of insect products may play a role in the future regarding the choice of larval product. It should be considered that processing of live insects can improve its storage properties (Veldkamp et al., 2012). Therefore, insect meals are storable for longer periods than live insects and further defatting can reduce the risk of lipid oxidation (Schiavone et al., 2017).

\section{Other poultry}

\section{Production performance}

BSF larvae have also been successfully incorporated in diets of other poultry species. The performance of Muscovy ducks remained unaffected by $9 \%$ inclusion of partially defatted BSF meal (Gariglio et al., 2019a). Likewise, performance parameters of Japanese quails remained unchanged when fed similar levels of BSF larval meal, of larvae that had been reared on layer mash. In contrast, meal of larvae raised on 50:50 fish offal and layer mash adversely affected quail performance, likely due to the odour and palatability of the meal (Woods et al., 2019). Turkeys showed higher FI and ADG, and lower FCR when they were provided with live BSF larvae (Veldkamp and van Niekerk, 2019).

\section{Product quality}

As reported in broilers (Schiavone et al., 2019), the administration of larval meal increased MUFA and decreased PUFA in quail meat (Cullere et al., 2019b). Furthermore, provision of BSF meal improved carcass and breast meat traits of quails fed meal, of larvae reared on layer mash, while meal of larvae raised on 50:50 fish offal and layer mash lowered the carcass weight of quails. In layer quails BSF meal provision affected egg production at levels higher than $3.18 \%$, this might have occurred due to lower palatability or darker colour of the feed. Moreover, egg shell thickness was negatively influenced at the highest level of BSF meal inclusion, likely caused by the shifted calcium and phosphorus levels in BSF meal compared to fishmeal (Suparman et al., 2020).

\section{Health and welfare}

In Japanese broiler quails, administration of BSF larval meal had a significant effect on health-related blood parameters. The wing web swelling index, an indicator for the immune system's lymphoproliferative capacity, was improved in BSF- 
fed groups. Also $\alpha 2$-globulin levels measured at day 27 and 37 were increased in the blood. Albumin-to-globulin ratio was unaffected. However, the results indicate a tendency of BSF-meal-fed groups to have lower values. Besides, the blood profile of quails was affected dependent on the prior rearing substrate of the BSF larvae. Broilers fed BSF larval meal of larvae reared on laver mash showed a higher secondary response, while quails fed larval meal of larvae reared on 50:50 layer mash and fish offal had lower $\gamma$-globulin levels at day 27 and higher lysozyme activity at day 37 compared to the control group. While blood parameters were altered, the treatments recorded no alteration of the microbial composition within the caeca. The results emphasise the immunomodulatory properties of BSF larval meal in quails (Pasotto et al., 2020). Furthermore, in Muscovy ducks BSF meal had only minor effects on the digestibility of nutrients. For instance, crude protein $(\mathrm{CP})$ digestibility was only reduced within the starter phase, likely due to the chitin content of the insect meal. However, with increasing age, birds seemed to be able to adapt to the feed source (Gariglio et al., 2019a). The health status of the ducks was unaffected, showing no effects on haematological traits (Gariglio et al., 2019b). Also in Japanese quails digestibility parameters were affected by the diet (Woods et al., 2019). When quails were given a choice between a diet containing insect meal and a control diet, birds preferred to consume the control feed. Feed colour might have played a role in this because BSF larval meal had a darker colour than SBM. Hence, these results emphasise once more the importance of appropriate feed properties when presented to poultry and highlight the power to modulate those characteristics through the choice of larval substrate (Woods et al., 2019). In this regard it is important to distinguish between the attractiveness of different insect products such as live insects and insect meal. Insects are a natural feed source for poultry. Visual cues and intrinsic mechanisms trigger poultry to eagerly ingest larvae. It was reported that turkeys consumed live larvae completely within two minutes after they were provided. In future studies this eagerness of consuming live larvae might be used to improve poultry welfare by stimulating natural behaviour (Veldkamp and van Niekerk, 2019). It is, therefore, important to investigate and distinguish the effect of different insect products on poultry production and behaviour.

\section{Future prospects of insects in poultry feed}

Insects have a good potential to be used in animal feed. Nonetheless, some hurdles need to be overcome. Especially in terms of legislation, new regulations need to be adopted to enable insect protein to be used in commercial poultry farming. Although currently only the provision of live insects is allowed in the EU, new legislation is expected within 2020 (IPIFF, 2018).
Feed and food safety are of fundamental importance when considering insects as feed. Major concerns are addressed regarding the provision of waste materials as larval substrate as a potential entrance route of chemical and biological contaminants into the food chain (Van Huis, 2020). At present, feeding of farm animals is merely permitted using vegetable materials, apart from a few exceptions (IPIFF, 2019). To maintain sustainable production and to obviate competition with human food and animal feed production new innovative ideas are required. Latest approaches identify the valorising of plant waste streams from industrial sectors for insect rearing, for instance by recycling brewery by-products (Bava et al., 2019; Jucker et al., 2019; Miranda et al., 2020; Ocio et al., 1979). Moreover, as reported for BSF, insects may add additional value to crop products, by metabolising undesired chemical contaminants such as mycotoxins. Mycotoxins are a major feed hazard because contaminated products are no longer suitable for feeding animals (Camenzuli et al., 2018). Investigations focussing on the fate of mycotoxins in insects and effects on larvae would be especially important to evaluate the suitability of the larvae for animal feed.

Recently, questions arose regarding the welfare of insects in mass production systems. In the past, insects have been considered non-sentient beings, unable to experience emotions (Van Huis, 2019). Responsible insect farming and feeding, however, includes ethical considerations. Studying insect welfare is a rather new field. While literature focussing on insect performance is available (Miranda et al., 2020; Schmitt et al., 2019), information considering insect welfare is scarce (but see Boppré and Vane-Wright, 2019). Also the effects of rearing condition on insect health are rarely investigated. To provide insect breeding and rearing companies with the tools to assess well-being and insect health and to develop appropriate killing methods in the future it is important to initiate studies on these aspects.

The use of plant waste products for insect rearing further promotes the establishment of a circular economy (Dicke, 2018). Various designs for business models have been discussed, including implementations on-farm to benefit primarily smallholder farmers in low and middle income countries (Chia et al., 2019) and large-scale farming in Europe (Veldkamp et al., 2012). Multiple options arise, benefitting different stages of the insect chain. Nonetheless, probably the most powerful factor determining the success of insects in feed is societal acceptance. Insect products are rather new to the western society. However, initial consumer studies turned out positive. While consumer attitudes for insect products as direct part of their diet are still rather low, consumers are especially willing to accept insects in animal feed (Onwezen et al., 2019; Verbeke et al., 2015). Consequently, the inclusion of insects in feed might pave the way for faster acceptance in human food. 
To support the inclusion of insects as feed, it is important to perform research into consumer acceptance and evaluate the economic robustness of using insects in feed considering the entire value chain from production to consumption.

\section{Conclusions}

The poultry sector is one of the most important providers of animal protein to humans. To satisfy future demands the sector is in transition towards more sustainable production. The main problems facing the industry are the need for sustainable feed protein sources and higher animal welfare, while maintaining economic viability. Both goals can potentially be met by using insects in poultry diets.

The use of insects in poultry feed is still subject to several uncertainties regarding legislation, substrate choice, ethical considerations and consumer attitude. On the other hand, insects have the potential to greatly contribute to the sustainable development goals (Barragán-Fonseca et al., 2020; Dicke, 2018). For instance, the use of insects in feed contributes to food security, circular agriculture, health, economic efficiency, and animal well-being, health and nutritional satisfaction. Because the insects-as-feed sector is still in its infancy more research is required. The current state of knowledge indicates that partial replacement of fishmeal or soybean meal by fly larvae in feed is beneficial for poultry and therefore these insects can be used as a valuable replacement for conventional protein sources. In this regard, one of the rather undiscovered fields is the use of live fly larvae for welfare enhancement. To contribute to a stable sector there is a need for standardised procedures for insect production and processing, clear distinction between insect products based on their nutritional composition, determination of optimal inclusion levels for insect products per poultry species, and production aim and the direct comparison of products from different insect species.

\section{Acknowledgements}

Our research has been supported by the Netherlands Organisation for Scientific Research (NWO; NWA programme, InsectFeed project, NWA.1160.18.144). We gratefully acknowledge Wikipedia for the structural formulae for chitin and lauric acid in Figure 1. We thank Yavanna Aartsma, Andreas Baumann, Walter Jansen and Marijke de Jong for constructive comments on a previous version of the manuscript.

\section{Conflict of interest}

The authors declare no conflict of interest.

\section{References}

Adeniji, A.A., 2007. Effect of replacing groundnut cake with maggot meal in the diet of broilers. International Journal of Poultry Science 6: 822-825. https://doi.org/10.3923/ijps.2007.822.825

Agunbiade, J.A., Adeyemi, O.A., Ashiru, O.M., Awojobi, H.A., Taiwo, A.A., Oke, D.B. and Adekunmisi, A.A., 2007. Replacement of fish meal with maggot meal in cassava-based layers' diets. The Journal of Poultry Science 44: 278-282. https://doi.org/10.2141/jpsa.44.278

Akpodiete, O., Ologhobo, A. and Onifade, A., 1998. Maggot meal as a substitute for fish meal in laying chicken diet. Ghana Journal of Agricultural Science 31: 137-142.

Andoh, M., Ueno, T. and Kawasaki, K., 2018. Tissue-dependent induction of antimicrobial peptide genes after body wall injury in house fly (Musca domestica) larvae. Drug Discoveries \& Therapeutics 12: 355-362. https://doi.org/10.5582/ddt.2018.01063 Attivi, K., Agboka, K., Mlaga, G.K., Oke, O.E., Teteh, A., Onagbesan, O. and Tona, K., 2020. Effect of black soldier fly (Hermetia illucens) maggots meal as a substitute for fish meal on growth performance, biochemical parameters and digestibility of broiler chickens. International Journal of Poultry Science 19: 75-80. https://doi. org/10.3923/ijps.2020.75.80

Augère-Granier, M.-L., 2019. The EU poultry meat and egg sector: Main features, challenges and prospects. European Parliamentary Research Service, Brussels, Belgium, 20 pp. https://doi. org/10.2861/33350

Azagoh, C., Ducept, F., Garcia, R., Rakotozafy, L., Cuvelier, M.-E., Keller, S., Lewandowski, R. and Mezdour, S., 2016. Extraction and physicochemical characterization of Tenebrio molitor proteins. Food Research International 88: 24-31. https://doi.org/10.2861/33350

Bahar, A. and Ren, D., 2013. Antimicrobial Peptides. Pharmaceuticals 6: 1543-1575. https://doi.org/10.3390/ph6121543

Barragán-Fonseca, K.Y., Barragán-Fonseca, K.B., Verschoor, G., Van Loon, J.J.A. and Dicke, M., 2020. Insects for peace. Current Opinion in Insect Science 40: 85-93. https://doi.org/10.1016/j. cois.2020.05.011

Bava, L., Jucker, C., Gislon, G., Lupi, D., Savoldelli, S., Zucali, M. and Colombini, S., 2019. Rearing of Hermetia illucens on different organic by-products: Influence on growth, waste reduction, and environmental impact. Animals 9: 289. https://doi.org/10.3390/ ani9060289

Bean, L. and Leeson, S., 2003. Long-term effects of feeding flaxseed on performance and egg fatty acid composition of brown and white hens. Poultry Science 82: 388-394. https://doi.org/10.1093/ ps/82.3.388

Biasato, I., Ferrocino, I., Dabbou, S., Evangelista, R., Gai, F., Gasco, L., Cocolin, L., Capucchio, M.T. and Schiavone, A., 2020. Black soldier fly and gut health in broiler chickens: insights into the relationship between cecal microbiota and intestinal mucin composition. Journal of Animal Science and Biotechnology 11: 11. https://doi. org/10.1186/s40104-019-0413-y

Boppré, M. and Vane-Wright, R.I., 2019. Welfare dilemmas created by keeping insects in captivity. In: Carere, C. and Mather, J. (eds) The welfare of invertebrate animals. Springer International Publishing, Cham, Switzerland, pp. 23-67. https://doi.org/10.1007/978-3-03013947-6_3 
Borrelli, L., Coretti, L., Dipineto, L., Bovera, F., Menna, F., Chiariotti, L., Nizza, A., Lembo, F. and Fioretti, A., 2017. Insect-based diet, a promising nutritional source, modulates gut microbiota composition and SCFAs production in laying hens. Scientific Reports 7: 16269. https://doi.org/10.1038/s41598-017-16560-6

Bovera, F., Loponte, R., Pero, M.E., Cutrignelli, M.I., Calabrò, S., Musco, N., Vassalotti, G., Panettieri, V., Lombardi, P., Piccolo, G., Di Meo, C., Siddi, G., Fliegerova, K. and Moniello, G., 2018. Laying performance, blood profiles, nutrient digestibility and inner organs traits of hens fed an insect meal from Hermetia illucens. Research in Veterinary Science 120: 86-93. https://doi.org/10.1016/j.rvsc.2018.09.006

Bulet, P., Hetru, C., Dimarcq, J.L. and Hoffmann, D., 1999. Antibacterial peptides in insects; structure and function. Evelopmental and Comparative Immunology 23: 329-344. https://doi.org/10.1016/ s0145-305x(99)00015-4

Camenzuli, L., Van Dam, R., de Rijk, T., Andriessen, R., van Schelt, J. and Van der Fels-Klerx, H.J.I., 2018. Tolerance and excretion of the mycotoxins aflatoxin B1, zearalenone, deoxynivalenol, and ochratoxin a by Alphitobius diaperinus and Hermetia illucens from contaminated substrates. Toxins 10: 91. https://doi.org/10.3390/ toxins 10020091

Chi, X., Ding, X., Peng, X., Li, X. and Fang, J., 2017. Effects of chitosan oligosaccharides supplementation on the cell cycle of immune organs in broilers. Kafkas Universitesi Veteriner Fakultesi Dergisi 23: 1003-1006. https://doi.org/10.9775/kvfd.2017.17997

Chia, S.Y., Tanga, C.M., van Loon, J.J. and Dicke, M., 2019. Insects for sustainable animal feed: inclusive business models involving smallholder farmers. Current Opinion in Environmental Sustainability 41: 23-30. https://doi.org/10.1016/j.cosust.2019.09.003

Clément, T., Joya, R., Bresson, C. and Clément, C., 2018. Market developments and policy evaluation aspects of the plant protein sector in the EU. Publications Office of the European Union, Brussels, Belgium, 160 pp. https://doi.org/10.2762/022741

Cole, J.N. and Nizet, V., 2016. Bacterial evasion of host antimicrobial peptide defenses. Microbiology Spectrum 4: 0006-2015. https:// doi.org/10.1128/microbiolspec.vmbf-0006-2015

Corr, S.A., Gentle, M.J., McCorquodale, C.C. and Bennett, D., 2003. The effect of morphology on walking ability in the modern broiler: a gait analysis study. Animal Welfare 12: 159-171.

Cullere, M., Schiavone, A., Dabbou, S., Gasco, L. and Dalle Zotte, A., 2019a. Meat quality and sensory traits of finisher broiler chickens fed with black soldier fly (Hermetia illucens L.) larvae fat as alternative fat source. Animals 9: 140. https://doi.org/10.3390/ani9040140

Cullere, M., Woods, M.J., van Emmenes, L., Pieterse, E., Hoffman, L.C. and Dalle Zotte, A., 2019b. Hermetia illucens larvae reared on different substrates in broiler quails: effect on physicochemical and sensory quality of the quail meat. Animals 9: 525. https://doi. org/10.3390/ani9080525

Cutrignelli, M.I., Messina, M., Tulli, F., Randazzi, B., Olivotto, I., Gasco, L., Loponte, R. and Bovera, F., 2018. Evaluation of an insect meal of the black soldier fly (Hermetia illucens) as soybean substitute: intestinal morphometry, enzymatic and microbial activity in laying hens. Research in Veterinary Science 117: 209-215. https://doi. org/10.1016/j.rvsc.2017.12.020
Dabbou, S., Gai, F., Biasato, I., Capucchio, M.T., Biasibetti, E., Dezzutto, D., Meneguz, M., Plachà, I., Gasco, L. and Schiavone, A., 2018. Black soldier fly defatted meal as a dietary protein source for broiler chickens: effects on growth performance, blood traits, gut morphology and histological features. Journal of Animal Science and Biotechnology 9: 49. https://doi.org/10.1186/s40104-018-0266-9

Damme, K. and Urselmans, S., 2013. Infrared beak treatment - a temporary solution? Lohmann Information 48: 61.

Dang, X.L., Wang, Y.S., Huang, Y.D., Yu, X.Q. and Zhang, W.Q., 2010. Purification and characterization of an antimicrobial peptide, insect defensin, from immunized house fly (Diptera: Muscidae). Journal of Medical Entomology 47: 1141-1145. https://doi.org/10.1603/ ME10016

De Haas, E.N., Kemp, B., Bolhuis, J.E., Groothuis, T. and Rodenburg, T.B., 2013. Fear, stress, and feather pecking in commercial white and brown laying hen parent-stock flocks and their relationships with production parameters. Poultry Science 92: 2259-2269. https:// doi.org/10.3382/ps.2012-02996

De Vries, M. and De Boer, I.J.M., 2010. Comparing environmental impacts for livestock products: a review of life cycle assessments. Livestock Science 128: 1-11. https://doi.org/10.1016/j. livsci.2009.11.007

Deng, X., Li, X., Liu, P., Yuan, S., Zang, J., Li, S. and Piao, X., 2008. Effect of chito-oligosaccharide supplementation on immunity in broiler chickens. Asian-Australasian Journal of Animal Sciences 21: 1651-1658. https://doi.org/10.5713/ajas.2008.80056

Dicke, M., 2018. Insects as feed and the sustainable development goals. Journal of Insects as Food and Feed 4: 147-156. https://doi. org/10.3920/JIFF2018.0003

Dixon, L.M., 2020. Slow and steady wins the race: the behaviour and welfare of commercial faster growing broiler breeds compared to a commercial slower growing breed. PLOS ONE 15: e0231006. https://doi.org/10.1371/journal.pone.0231006

Dixon, L.M. and Duncan, I.J.H., 2010. Changes in substrate access did not affect early feather-pecking behavior in two strains of laying hen chicks. Journal of Applied Animal Welfare Science 13: 1-14. https://doi.org/10.1080/10888700903369248

Elahi, U., Ma, Y., Wu, S., Wang, J., Zhang, H. and Qi, G., 2019. Growth performance, carcass characteristics, meat quality and serum profile of broiler chicks fed on housefly maggot meal as a replacement of soybean meal. Journal of Animal Physiology and Animal Nutrition 1-10. DOI: https://doi.org/10.1111/jpn.13265

Elahi, U., Wang, J., Ma, Y., Wu, S., Wu, J., Qi, G. and Zhang, H., 2020. Evaluation of yellow mealworm meal as a protein feedstuff in the diet of broiler chicks. Animals 10: 224. https://doi.org/10.3390/ ani10020224

Elnesr, S.S., Alagawany, M., Elwan, H.A.M., Fathi, M.A. and Farag, M.R., 2020. Effect of sodium butyrate on intestinal health of poultry - a review. Annals of Animal Science 20: 29-41. https://doi.org/10.2478/ aoas-2019-0077

Elwert, C., Knips, I. and Katz, P., 2010. A novel protein source: maggot meal of the black soldier fly (Hermetia illucens) in broiler feed. In: Gierus, M., Kluth, H., Bulang, M. and Kluge, H. (eds) Tagung Schweine- und Geflügelernährung. Institut für Agrarund Ernährungswissenschaften, Universität Halle-Wittenberg, Germany, pp. 140-142. 
European Commission (EC), 2016. Report from the commission to the European Parliament and the Coucil on the impact of genetic selection on the welfare of chickens kept for meat production. Brussels, Belgium. Available at: https://tinyurl.com/y3cnlsvq.

European Commission (EC), 2017. Commission Regulation (EU) 2017/893 of 24 May 2017 amending Annexes I and IV to Regulation (EC) No 999/2001 of the European Parliament and of the Council and Annexes X, XIV and XV to Commission Regulation (EU) No $142 / 2011$ as regards the provisions on processed animal protein. Official Journal of the European Union L 138: 92-116. Available at: http://data.europa.eu/eli/reg/2017/893/oj.

European Commission (EC), 2018. EU agricultural outlook for markets and income 2018-2030. EC, Brussels, Belgium, 128 pp. Available at: https://tinyurl.com/yy8kdfup.

European Commission (EC), 2019. EU feed protein balance sheet 2018-19. EC, Brussels, Belgium. Available at: https://tinyurl.com/ y4at6cpq.

Fanatico, A.C., Pillai, P.B., Hester, P.Y., Falcone, C., Mench, J.A., Owens, C.M. and Emmert, J.L., 2008. Performance, livability, and carcass yield of slow- and fast-growing chicken genotypes fed low-nutrient or standard diets and raised indoors or with outdoor access. Poultry Science 87: 1012-1021. https://doi.org/10.3382/ps.2006-00424

FAOSTAT, 2019. Annual population. FAO, Rome, Italy. Available at: http://www.fao.org/faostat/en/\#data/OA.

FAOSTAT, 2020a. Livestock primary. FAO, Rome, Italy. Available at: http://www.fao.org/faostat/en/\#data/QL.

FAOSTAT, 2020b. New food balances. FAO, Rome, Italy. Available at: http://www.fao.org/faostat/en/\#data/FBS.

Farrell, D., 2013. The role of poultry in human nutrition. Poultry Development Review. FAO, Rome, Italy, pp. 2-3. Available at: http:// www.fao.org/3/i3531e/i3531e00.htm.

Fernandez, S.R., Aoyagi, S., Han, Y., Parsons, C.M. and Baker, D.H., 1994. Limiting order of amino acids in corn and soybean meal for growth of the chick. Poultry Science 73: 1887-1896. https://doi. org/10.3382/ps.0731887

Fernyhough, M., Nicol, C.J., Van de Braak, T., Toscano, M.J. and Tønnessen, M., 2020. The ethics of laying hen genetics. Journal of Agricultural and Environmental Ethics 33: 15-36. https://doi. org/10.1007/s10806-019-09810-2

Finke, M.D., 2007. Estimate of chitin in raw whole insects. Zoo Biology 26: 105-115. https://doi.org/10.1002/zoo.20123

Finke, M.D., 2013. Complete nutrient content of four species of feeder insects. Zoo Biology 32: 27-36. https://doi.org/10.1002/zoo.21012

Fitches, E.C., Dickinson, M., De Marzo, D., Wakefield, M.E., Charlton, A.C. and Hall, H., 2019. Alternative protein production for animal feed: Musca domestica productivity on poultry litter and nutritional quality of processed larval meals. Journal of Insects as Food and Feed 5: 77-88. https://doi.org/10.3920/JIFF2017.0061

Flachowsky, G., Meyer, U. and Südekum, K.-H., 2018. Invited review: Resource inputs and land, water and carbon footprints from the production of edible protein of animal origin. Archives Animal Breeding 61: 17-36. https://doi.org/10.5194/aab-61-17-2018
Food and Agriculture Organization of the United Nations (FAO), 2008. Poultry in the $21^{\text {st }}$ century: avian influenza and beyond. Proceedings of the International Poultry Conference, held 5-7 November 2007, Bangkok, Thailand. Thieme, O. and Pilling, D. (eds) FAO Animal Production and Health Proceedings, No. 9., Italy, Rome.

Food and Agriculture Organization of the United Nations (FAO), 2009. The state of food and agriculture: Livestock in the balance. FAO, Rome, Italy. https://doi.org/10.18356/6e4ebb75-en

Food and Agriculture Organization of the United Nations (FAO), 2018. The future of food and agriculture - alternative pathways to 2050. FAO, Rome, Italy, 224 pp.

Gariglio, M., Dabbou, S., Biasato, I., Capucchio, M.T., Colombino, E., Hernández, F., Madrid, J., Martínez, S., Gai, F., Caimi, C., Oddon, S.B., Meneguz, M., Trocino, A., Vincenzi, R., Gasco, L. and Schiavone, A., 2019a. Nutritional effects of the dietary inclusion of partially defatted Hermetia illucens larva meal in muscovy duck. Journal of Animal Science and Biotechnology 10: 37. https://doi. org/10.1186/s40104-019-0344-7

Gariglio, M., Dabbou, S., Crispo, M., Biasato, I., Gai, F., Gasco, L., Piacente, F., Odetti, P., Bergagna, S., Plachà, I., Valle, E., Colombino, E., Capucchio, M.T. and Schiavone, A., 2019b. Effects of the dietary inclusion of partially defatted black soldier fly (Hermetia illucens) meal on the blood chemistry and tissue (spleen, liver, thymus, and bursa of Fabricius) histology of muscovy ducks (Cairina moschata domestica). Animals 9: 307. https://doi.org/10.3390/ani9060307

Gasco, L., Finke, M. and Van Huis, A., 2018. Can diets containing insects promote animal health? Journal of Insects as Food and Feed 4: 1-4. https://doi.org/10.3920/JIFF2018.x001

Ghaly, A.E. and Alkoaik, F.N., 2009. The yellow mealworm as a novel source of protein. American Journal of Agricultural and Biological Science 4: 319-331. https://doi.org/10.3844/ajabssp.2009.319.331 Giles, T., Sakkas, P., Belkhiri, A., Barrow, P., Kyriazakis, I. and Foster, N., 2019. Differential immune response to Eimeria maxima infection in fast- and slow-growing broiler genotypes. Parasite Immunology 41: e12660. https://doi.org/10.1111/pim.12660

Hahn, T., Roth, A., Febel, E., Fijalkowska, M., Schmitt, E., Arsiwalla, T. and Zibek, S., 2018. New methods for high-accuracy insect chitin measurement. Journal of the Science of Food and Agriculture 98: 5069-5073. https://doi.org/10.1002/jsfa.9044

Hall, H.N., Masey O'Neill, H.V., Scholey, D., Burton, E., Dickinson, M. and Fitches, E.C., 2018. Amino acid digestibility of larval meal (Musca domestica) for broiler chickens. Poultry Science 97: 12901297. https://doi.org/10.3382/ps/pex433

Hao, Y.J., Jing, Y.J., Qu, H., Li, D.S. and Du, R.Q., 2008. Purification and characterization of a thermal stable antimicrobial protein from housefly larvae, Musca domestica, induced by ultrasonic wave. Acta Biologica Hungarica 59: 289-304. https://doi.org/10.1556/ ABiol.59.2008.3.3

Harms, R.H. and Ivey, F.J., 1993. Performance of commercial laying hens fed various supplemental amino acids in a corn-soybean meal diet. Journal of Applied Poultry Research 2: 273-282. https://doi. org/10.1093/japr/2.3.273

Hecht, S.B., 2005. Soybeans, development and conservation on the amazon frontier. Development and Change 36: 375-404. https:// doi.org/10.1111/j.0012-155X.2005.00415.x 
Heshmatollah, K., 2007. Preference of broiler chicks for color of lighting and feed. The Journal of Poultry Science 44: 213-219.

International Egg Commission, 2011. Annual Review 2011. International Egg Commission, London, UK. Available at: https:// tinyurl.com/yxjkqmoy.

International Egg Commission, 2015. Annual Review 2015. International Egg Commission, London, UK. Available at: https:// tinyurl.com/y4urqxpx.

International Egg Commission, 2019. Annual Review 2019. International Egg Commission, London, UK.

International Platform of Insects for Food and Feed (IPIFF), 2018. The European insect sector today: challanges, oppotunities and regulatory landscape. IPIFF vision paper on the future of the insect sector towards 2030. IPIFF, Brussels, Belgium. Available at: https:// tinyurl.com/y3o5scnh.

International Platform of Insects for Food and Feed (IPIFF), 2019. Guide on good hygiene practice. IPIFF, Brussels, Belgium. Available at: https://tinyurl.com/yc978kx8.

Ipema, A.F., Gerrits, W.J.J., Bokkers, E.A.M., Kemp, B. and Bolhuis, J.E., 2020. Provisioning of live black soldier fly larvae (Hermetia illucens) benefits broiler activity and leg health in a frequency- and dose-dependent manner. Applied Animal Behaviour Science 230: 105082. https://doi.org/10.1016/j.applanim.2020.105082

Irawan, A.C., Rahmawati, N., Astuti, D. and Wibawan, I., 2019. Supplementation of black soldier fly (Hermetia illucens) on activity and capacity phagocytic macrophage of laying hens. Jurnal Ilmu Ternak dan Veteriner 24: 182-187. https://doi.org/10.14334/jitv. v24i4.2025

Józefiak, A. and Engberg, R., 2017. Insect proteins as a potential source of antimicrobial peptides in livestock production. A review. Journal of Animal and Feed Sciences 26: 87-99. https://doi.org/10.22358/ jafs/69998/2017

Józefiak, D., Józefiak, A., Kierończyk, B., Rawski, M., Świątkiewicz, S., Długosz, J. and Engberg, R.M., 2016. Insects - a natural nutrient source for poultry - a review. Annals of Animal Science 16: 297313. https://doi.org/10.1515/aoas-2016-0010

Jucker, C., Leonardi, M.G., Rigamonti, I., Lupi, D. and Savoldelli, S., 2019. Brewery's waste streams as a valuable substrate for black soldier fly Hermetia illucens (Diptera: Stratiomyidae). Journal of Entomological and Acarological Research 51: 8876. https://doi. org/10.4081/jear.2019.8876

Jucker, C., Lupi, D., Moore, C.D., Leonardi, M.G. and Savoldelli, S., 2020. Nutrient recapture from insect farm waste: bioconversion with Hermetia illucens (L.) (Diptera: Stratiomyidae). Sustainability 12: 362. https://doi.org/10.3390/su12010362

Kaya, M., Erdogan, S., Mol, A. and Baran, T., 2015. Comparison of chitin structures isolated from seven Orthoptera species. International Journal of Biological Macromolecules 72: 797-805. https://doi.org/10.1016/j.ijbiomac.2014.09.034

Khan, M., Chand, N., Khan, S., Khan, R. and Sultan, A., 2018a. Utilizing the house fly (Musca domestica) larva as an alternative to soybean meal in broiler ration during the starter phase. Revista Brasileira de Ciência Avícola 20: 9-14. https://doi.org/10.1590/1806-90612017-0529
Khan, S., Khan, R.U., Alam, W. and Sultan, A., 2018b. Evaluating the nutritive profile of three insect meals and their effects to replace soya bean in broiler diet. Journal of Animal Physiology and Animal Nutrition 102: e662-e668. https://doi.org/10.1111/jpn.12809

Khan, S., Khan, R.U., Sultan, A., Khan, M., Hayat, S.U. and Shahid, M.S., 2016. Evaluating the suitability of maggot meal as a partial substitute of soya bean on the productive traits, digestibility indices and organoleptic properties of broiler meat. Journal of Animal Physiology and Animal Nutrition 100: 649-656. https:// doi.org/10.1111/jpn.12419

Kim, S.A. and Rhee, M.S., 2013. Marked synergistic bactericidal effects and mode of action of medium-chain fatty acids in combination with organic acids against Escherichia coli O157: H7. Applied and Environmental Microbiology 79: 6552-6560. https://doi.org/10.1128/ AEM.02164-13

Larouche, J., 2019. Processing methods for the black soldier fly (Hermetia illucens) larvae : from feed withdrawal periods to killing methods. M.Sc. thesis, Université Laval, Québec, Canada, 100 pp.

Lee, C.G., Da Silva, C.A., Lee, J.-Y., Hartl, D. and Elias, J.A., 2008. Chitin regulation of immune responses: an old molecule with new roles. Current Opinion in Immunology 20: 684-689. https://doi. org/10.1016/j.coi.2008.10.002

Leenstra, F., Maurer, V., Bestman, M., Van Sambeek, F., Zeltner, E., Reuvekamp, B., Galea, F. and Van Niekerk, T., 2012. Performance of commercial laying hen genotypes on free range and organic farms in Switzerland, France and the Netherlands. British Poultry Science 53: 282-290. https://doi.org/10.1080/00071668.2012.703774 Li, X.J., Piao, X.S., Kim, S.W., Liu, P., Wang, L., Shen, Y.B., Jung, S.C. and Lee, H.S., 2007. Effects of chito-oligosaccharide supplementation on performance, nutrient digestibility, and serum composition in broiler chickens. Poultry Science 86: 1107-1114. https://doi. org/10.1093/ps/86.6.1107

Li, Z., Mao, R., Teng, D., Hao, Y., Chen, H., Wang, X., Wang, X., Yang, N. and Wang, J., 2017. Antibacterial and immunomodulatory activities of insect defensins-DLP2 and DLP4 against multidrugresistant Staphylococcus aureus. Scientific Reports 7: 12124. https:// doi.org/10.1038/s41598-017-10839-4

Lund, T.B., McKeegan, D.E.F., Cribbin, C. and Sandøe, P., 2016. Animal ethics profiling of vegetarians, vegans and meat eaters. Anthrozoös 29: 89-106. https://doi.org/10.1080/08927936.2015.1083192

Makkar, H.P.S., Tran, G., Heuzé, V. and Ankers, P., 2014. Stateof-the-art on use of insects as animal feed. Animal Feed Science and Technology 197: 1-33. https://doi.org/10.1016/j. anifeedsci.2014.07.008

Marono, S., Loponte, R., Lombardi, P., Vassalotti, G., Pero, M.E., Russo, F., Gasco, L., Parisi, G., Piccolo, G., Nizza, S., Di Meo, C., Attia, Y.A. and Bovera, F., 2017. Productive performance and blood profiles of laying hens fed Hermetia illucens larvae meal as total replacement of soybean meal from 24 to 45 weeks of age. Poultry Science 96: 1783-1790. https://doi.org/10.3382/ps/pew461

Meylaers, K., Clynen, E., Daloze, D., DeLoof, A. and Schoofs, L., 2004. Identification of 1-lysophosphatidylethanolamine (C16:1) as an antimicrobial compound in the housefly, Musca domestica. Insect Biochemistry and Molecular Biology 34: 43-49. https://doi. org/10.1016/j.ibmb.2003.09.001 
Miranda, C.D., Cammack, J.A. and Tomberlin, J.K., 2020. Life-history traits of house fly, Musca domestica L. (Diptera: Muscidae), reared on three manure types. Journal of Insects as Food and Feed 6: 81-90. https://doi.org/10.3920/JIFF2019.0001

Moniello, G., Ariano, A., Panettieri, V., Tulli, F., Olivotto, I., Messina, M., Randazzo, B., Severino, L., Piccolo, G., Musco, N., Addeo, N., Hassoun, G. and Bovera, F., 2019. Intestinal morphometry, enzymatic and mivrobial activity in laying hens fed different levels of Hermetia illucens larvae meal and toxic elements content in the insect meal and diets. Animals 9: 86. https://doi.org/10.3390/ ani9030086

Mottet, A., de Haan, C., Falcucci, A., Tempio, G., Opio, C. and Gerber, P., 2017. Livestock: on our plates or eating at our table? A new analysis of the feed/food debate. Global Food Security 14: 1-8. https://doi.org/10.1016/j.gfs.2017.01.001

Nicol, C.J., Bestman, M., Gilani, A.-M., De Haas, E.N., De Jong, I.C., Lambton, S., Wagenaar, J.P., Weeks, C.A. and Rodenburg, T.B., 2013. The prevention and control of feather pecking: application to commercial systems. World's Poultry Science Journal 69: 775-788. https://doi.org/10.1017/S0043933913000809

Nie, C., Zhang, Z., Zheng, J., Sun, H., Ning, Z., Xu, G., Yang, N. and Qu, L., 2016. Genome-wide association study revealed genomic regions related to white/red earlobe color trait in the Rhode Island Red chickens. BMC Genetics 17: 115. https://doi.org/10.1186/ s12863-016-0422-1

Ochoa Sanabria, C., Hogan, N., Madder, K., Gillott, C., Blakley, B., Reaney, M., Beattie, A. and Buchanan, F., 2019. Yellow mealworm larvae (Tenebrio molitor) fed mycotoxin-contaminated wheat-a possible safe, sustainable protein source for animal feed? Toxins 11: 282. https://doi.org/10.3390/toxins 11050282

Ocio, E., Viñaras, R. and Rey, J.M., 1979. House fly larvae meal grown on municipal organic waste as a source of protein in poultry diets. Animal Feed Science and Technology 4: 227-231. https://doi. org/10.1016/0377-8401(79)90016-6

Odén, K., Keeling, L.J. and Algers, B., 2002. Behaviour of laying hens in two types of aviary systems on 25 commercial farms in Sweden. British Poultry Science 43: 169-181. https://doi. org/10.1080/00071660120121364

Okah, U. and Onwujiariri, E.B., 2012. Performance of finisher broiler chickens fed maggot meal as a replacement for fish meal. Journal of Agricultural Technology 8: 471-477.

Olsen, R.L. and Hasan, M.R., 2012. A limited supply of fishmeal: Impact on future increases in global aquaculture production. Trends in Food Science and Technology 27: 120-128. https://doi.org/10.1016/j. tifs.2012.06.003

Onbaşılar, E.E., Ünal, N., Erdem, E., Kocakaya, A. and Yaranoğlu, B., 2015. Production performance, use of nest box, and external appearance of two strains of laying hens kept in conventional and enriched cages. Poultry Science 94: 559-564. https://doi.org/10.3382/ ps/pev009

Onwezen, M.C., Van den Puttelaar, J., Verain, M.C.D. and Veldkamp, T., 2019. Consumer acceptance of insects as food and feed: The relevance of affective factors. Food Quality and Preference 77: 5163. https://doi.org/10.1016/j.foodqual.2019.04.011
Organisation for Economic Co-operation and Development / Food and Agriculture Organisation (OECD/FAO), 2019. OECDFAO agricultural outlook 2019-2028. Food and and Agriculture Organization of the United Nation, Rome, Italy. Available at: https:// doi.org/10.1787/agr_outlook-2019-en.

Park, S.I., Kim, J.W. and Yoe, S.M., 2015. Purification and characterization of a novel antibacterial peptide from black soldier fly (Hermetia illucens) larvae. Developmental and Comparative Immunology 52: 98-106. https://doi.org/10.1016/j.dci.2015.04.018

Pasotto, D., van Emmenes, L., Cullere, M., Giaccone, V., Pieterse, E., Hoffman, L.C. and Dalle Zotte, A., 2020. Inclusion of Hermetia illucens larvae reared on fish offal to the diet of broiler quails: effect on immunity and caecal microbial populations. Czech Journal of Animal Science 65: 213-223. https://doi.org/10.17221/60/2020-CJAS

Qi, X., Li, Z., Akami, M., Mansour, A. and Niu, C., 2019. Fermented crop straws by Trichoderma viride and Saccharomyces cerevisiae enhanced the bioconversion rate of Musca domestica (Diptera: Muscidae). Environmental Science and Pollution Research 26: 29388-29396. https://doi.org/10.1007/s11356-019-06101-1

Quentin, M., Bouvarel, I., Berri, C., Le Bihan-Duval, E., Baéza, E., Jégo, Y. and Picard, M., 2003. Growth, carcass composition and meat quality response to dietary concentrations in fast-, medium- and slow-growing commercial broilers. Animal Research 52: 65-77. https://doi.org/10.1051/animres:2003005

Radulović, S., Pavlović, M., Šefer, D., Katoch, S., Hadži-Milić, M., Jovanović, D., Grdović, S. and Marković, R., 2018. Effects of housefly larvae (Musca domestica) dehydrated meal on production performances and sensory properties of broiler meat. Thai Journal of Veterinary Medicine 48: 63-70.

Rezaei, M., Yngvesson, J., Gunnarsson, S., Jönsson, L. and Wallenbeck, A., 2018. Feed efficiency, growth performance, and carcass characteristics of a fast- and a slower-growing broiler hybrid fed low- or high-protein organic diets. Organic Agriculture 8: 121-128. https://doi.org/10.1007/s13165-017-0178-6

Rinaudo, M., 2006. Chitin and chitosan: properties and applications. Progress in Polymer Science 31: 603-632. https://doi.org/10.1016/j. progpolymsci.2006.06.001

Saatkamp, H.W., Vissers, L.S.M., Van Horne, P.L.M. and De Jong, I.C., 2019. Transition from conventional broiler meat to meat from production concepts with higher animal welfare: experiences from the Netherlands. Animals 9: 483. https://doi.org/10.3390/ani9080483

Sakkas, P., Oikeh, I., Blake, D.P., Nolan, M.J., Bailey, R.A., Oxley, A., Rychlik, I., Lietz, G. and Kyriazakis, I., 2018. Does selection for growth rate in broilers affect their resistance and tolerance to Eimeria maxima? Veterinary Parasitology 258: 88-98. https://doi. org/10.1016/j.vetpar.2018.06.014

Schiavone, A., Dabbou, S., Petracci, M., Zampiga, M., Sirri, F., Biasato, I., Gai, F. and Gasco, L., 2019. Black soldier fly defatted meal as a dietary protein source for broiler chickens: effects on carcass traits, breast meat quality and safety. Animal 13: 2397-2405. https://doi. org/10.1017/S1751731119000685 
Schiavone, A., De Marco, M., Martínez, S., Dabbou, S., Renna, M., Madrid, J., Hernandez, F., Rotolo, L., Costa, P., Gai, F. and Gasco, L., 2017. Nutritional value of a partially defatted and a highly defatted black soldier fly larvae (Hermetia illucens). Journal of Animal Science and Biotechnology 8: 1-9. https://doi.org/10.1186/ s40104-017-0181-5

Schmitt, E., Belghit, I., Johansen, J., Leushuis, R., Lock, E.J., Melsen, D., Ramasamy Shanmugam, R.K., Van Loon, J. and Paul, A., 2019. Growth and safety assessment of feed streams for black soldier fly larvae: a case study with aquaculture sludge. Animals 9: 189. https:// doi.org/10.3390/ani9040189

Secci, G., Bovera, F., Nizza, S., Baronti, N., Gasco, L., Conte, G., Serra, A., Bonelli, A. and Parisi, G., 2018. Quality of eggs from Lohmann Brown Classic laying hens fed black soldier fly meal as substitute for soya bean. Animal 12: 2191-2197. https://doi.org/10.1017/ S1751731117003603

Secci, G., Bovera, F., Parisi, G. and Moniello, G., 2020. Quality of eggs and albumen technological properties as affected by Hermetia illucens larvae meal in hens' diet and hen age. Animals 10: 1-12. https://doi.org/10.3390/ani10010081

Shahidi, F. and Abuzaytoun, R., 2005. Chitin, chitosan, and co-products: chemistry, production, applications, and health effects. Advances in Food and Nutrition Research 49: 93-135. https://doi.org/10.1016/ S1043-4526(05)49003-8

Singh, R., Cheng, K.M. and Silversides, F.G., 2009. Production performance and egg quality of four strains of laying hens kept in conventional cages and floor pens. Poultry Science 88: 256-264. https://doi.org/10.3382/ps.2008-00237

Skrivanova, E., Marounek, M., Benda, V. and Brezina, P., 2006. Susceptibility of Escherichia coli, Salmonella sp. and Clostridium perfringens to organic acids and monolaurin. Veterinarni Medicina 51: 81-88.

Sogari, G., Amato, M., Biasato, I., Chiesa, S. and Gasco, L., 2019. The potential role of insects as feed: a multi-perspective review. Animals 9: 119. https://doi.org/10.3390/ani9040119

Stadig, L., 2019. Vleeskuikenconcepten in Nederland - een vegelijking op gebied van dierenwelzijn. Nederlandse Vereniging tot Bescherming van Dieren, Den Haag, the Netherlands. Available at: https://tinyurl.com/yyh9mc9a.

Star, L., Arsiwalla, T., Molist, F., Leushuis, R., Dalim, M. and Paul, A., 2020. Gradual provision of live black soldier fly (Hermetia illucens) larvae to older laying hens: effect on production performance, egg quality, feather condition and behavior. Animals 10: 216. https:// doi.org/10.3390/ani10020216

Struthers, S., Classen, H.L., Gomis, S., Crowe, T.G. and SchweanLardner, K., 2019. The impact of beak tissue sloughing and beak shape variation on the behavior and welfare of infrared beak-treated layer pullets and hens. Poultry Science 98: 4269-4281. https://doi. org/10.3382/ps/pez274.

Suparman, Purwanti, S. and Nahariah, N., 2020. Substitution of fish meal with black soldier fly larvae (Hermetia illucens) meal to eggs production and physical quality of quail (Coturnix coturnix japonica) eggs. IOP Conference Series: Earth and Environmental Science 492: 012014. https://doi.org/10.1088/1755-1315/492/1/012014
Suzuki, M., Fujimoto, W., Goto, M., Morimatsu, M., Syuto, B. and Iwanaga, T., 2002. Cellular expression of gut chitinase mRNA in the gastrointestinal tract of mice and chickens. Journal of Histochemistry \& Cytochemistry 50: 1081-1089. https://doi. org/10.1177/002215540205000810

Tabata, E., Kashimura, A., Wakita, S., Ohno, M., Sakaguchi, M., Sugahara, Y., Kino, Y., Matoska, V., Bauer, P.O. and Oyama, F., 2017. Gastric and intestinal proteases resistance of chicken acidic chitinase nominates chitin-containing organisms for alternative whole edible diets for poultry. Scientific Reports 7: 1-11. https:// doi.org/10.1038/s41598-017-07146-3

Tallentire, C.W., Leinonen, I. and Kyriazakis, I., 2018. Artificial selection for improved energy efficiency is reaching its limits in broiler chickens. Scientific Reports 8: 1-10. https://doi.org/10.1038/ s41598-018-19231-2

Timbermont, L., Lanckriet, A., Dewulf, J., Nollet, N., Schwarzer, K., Haesebrouck, F., Ducatelle, R. and Van Immerseel, F., 2010. Control of Clostridium perfringens -induced necrotic enteritis in broilers by target-released butyric acid, fatty acids and essential oils. Avian Pathology 39: 117-121. https://doi.org/10.1080/03079451003610586

Uitdehaag, K., Komen, H., Rodenburg, T.B., Kemp, B. and Van Arendonk, J., 2008. The novel object test as predictor of feather damage in cage-housed Rhode Island Red and White Leghorn laying hens. Applied Animal Behaviour Science 109: 292-305. https://doi. org/10.1016/j.applanim.2007.03.008

Van Horne, P.L.M., 2018. Competitiveness of the EU poultry meat sector, base year 2017: international comparison of production costs. Report 2018-116. Wageningen Economic Research, Wageningen, the Netherlands, 40 pp. Available at: https://library.wur.nl/WebQuery/ wurpubs/544594.

Van Huis, A., 2019. Welfare of farmed insects. Journal of Insects as Food and Feed 5: 159-162. https://doi.org/10.3920/JIFF2019.x004

Van Huis, A., 2020. Insects as food and feed, a new emerging agricultural sector: a review. Journal of Insects as Food and Feed 6: 27-44. https://doi.org/10.3920/JIFF2019.0017

Van Huis, A., Van Itterbeeck, J., Klunder, H., Mertens, E., Halloran, A., Muir, G. and Vantomme, P., 2013. Edible insects. Future prospects for food and feed security. Food And Agriculture Organization of the United Nations Forestry Paper 171, FAO, Rome, Italy, 201 pp. https://doi.org/10.1017/CBO9781107415324.004

Van Krimpen, M.M. and Hendriks, W.H., 2019. 13: Novel protein sources in animal nutrition: considerations and examples. In: Hendriks, W.H., Verstegen, M.W.A. and Babinszky, L. (eds) Poultry and pig nutrition - Challenges of the $21^{\text {st }}$ century. Wageningen Academic Publishers, Wageningen, the Netherlands, pp. 279-305. https://doi.org/10.3920/978-90-8686-884-1_13

Veldkamp, T. and Bosch, G., 2015. Insects : a protein-rich feed ingredient in pig and poultry diets. Animal Frontiers 5: 45-50. https://doi.org/10.2527/af.2015-0019

Veldkamp, T., Van Duinkerken, G., Van Huis, A., Lakemond, C.M.M., Ottevanger, E., Bosch, G. and Van Boekel, M.A.J.S., 2012. Insects as a sustainable feed ingredient in pig and poultry diets - a feasibility study. Livestock Research Report 638, Wageningen UR Livestock Research, Wageningen; the Netherlands. Available at: https://tinyurl. com/yxu35gh9. 


\section{A. Dörper et al.}

Veldkamp, T. and Van Niekerk, T.G.C.M., 2019. Live black soldier fly larvae (Hermetia illucens) for turkey poults. Journal of Insects as Food and Feed 5: 301-311. https://doi.org/10.3920/JIFF2018.0031

Verbeke, W., Spranghers, T., De Clercq, P., De Smet, S., Sas, B. and Eeckhout, M., 2015. Insects in animal feed: acceptance and its determinants among farmers, agriculture sector stakeholders and citizens. Animal Feed Science and Technology 204: 72-87. https:// doi.org/10.1016/j.anifeedsci.2015.04.001

Vissers, L.S.M., De Jong, I.C., Van Horne, P.L.M. and Saatkamp, H.W., 2019. Global prospects of the cost-efficiency of broiler welfare in middle-segment production systems. Animals 9: 1-17. https://doi. org/10.3390/ani9070473

Vogel, H., Müller, A., Heckel, D.G., Gutzeit, H. and Vilcinskas, A., 2018. Nutritional immunology: diversification and diet-dependent expression of antimicrobial peptides in the black soldier fly Hermetia illucens. Developmental and Comparative Immunology 78: 141-148. https://doi.org/10.1016/j.dci.2017.09.008

Wallenbeck, A., Wilhelmsson, S., Jönsson, L., Gunnarsson, S. and Yngvesson, J., 2016. Behaviour in one fast-growing and one slowergrowing broiler (Gallus gallus domesticus) hybrid fed a high- or low-protein diet during a 10-week rearing period. Acta Agriculturae Scandinavica, Section A - Animal Science 66: 168-176. https:// doi.org/10.1080/09064702.2017.1303081

Wang, H., Zhang, Z., Czapar, G.F., Winkler, M.K.H. and Zheng, J., 2013. A full-scale house fly (Diptera: Muscidae) larvae bioconversion system for value-added swine manure reduction. Waste Management \& Research 31: 223-231. https://doi.org/10.1177/0734242X12469431
Wang, Z., Wang, J., Zhang, Y., Wang, X., ZhangG, X., Liu, Y., Xi, J., Tong, H., Wang, Q., Jia, B. and Sehn, H., 2017. Antimicrobial peptides in housefly larvae (Musca domestica) affect intestinal Lactobacillus acidophilus and mucosal epithelial cells in Salmonella pullorum-infected chickens. Kafkas Universitesi Veteriner Fakultesi Dergisi 23: 423-430. https://doi.org/10.9775/kvfd.2016.16901

Wilhelmsson, S., Yngvesson, J., Jönsson, L., Gunnarsson, S. and Wallenbeck, A., 2019. Welfare Quality ${ }^{\circledR}$ assessment of a fast-growing and a slower-growing broiler hybrid, reared until 10 weeks and fed a low-protein, high-protein or mussel-meal diet. Livestock Science 219: 71-79. https://doi.org/10.1016/j.livsci.2018.11.010

Wong, C., Rosli, S., Uemura, Y., Ho, Y.C., Leejeerajumnean, A., Kiatkittipong, W., Cheng, C.-K., Lam, M.-K. and Lim, J.-W., 2019. Potential protein and biodiesel sources from black soldier fly larvae: insights of larval harvesting instar and fermented feeding medium. Energies 12: 1570. https://doi.org/10.3390/en12081570

Woods, M.J., Cullere, M., Van Emmenes, L., Vincenzi, S., Pieterse, E., Hoffman, L.C. and Zotte, A.D., 2019. Hermetia illucens larvae reared on different substrates in broiler quail diets: effect on apparent digestibility, feed-choice and growth performance. Journal of Insects as Food and Feed 5: 89-98. https://doi.org/10.3920/JIFF2018.0027 Woods, M.J., Goosen, N.J., Hoffman, L.C. and Pieterse, E., 2020. A simple and rapid protocol for measuring the chitin content of Hermetia illucens (L.) (Diptera: Stratiomyidae) larvae. Journal of Insects as Food and Feed 6:285-290. https://doi.org/10.3920/ JIFF2019.0030 